University of California, Hastings College of the Law UC Hastings Scholarship Repository

Faculty Scholarship

2015

\title{
Wargaming Financial Crises: The Problem of (In)Experience and Regulator Expertise
}

John Crawford

UC Hastings College of the Law, crawforj@uchastings.edu

Follow this and additional works at: https://repository.uchastings.edu/faculty_scholarship

\section{Recommended Citation}

John Crawford, Wargaming Financial Crises: The Problem of (In)Experience and Regulator Expertise, 34 Rev. Banking \& Fin. L. 111 (2015).

Available at: https://repository.uchastings.edu/faculty_scholarship/1458

This Article is brought to you for free and open access by UC Hastings Scholarship Repository. It has been accepted for inclusion in Faculty Scholarship by an authorized administrator of UC Hastings Scholarship Repository. For more information, please contact wangangela@uchastings.edu. 


\title{
WARgaming Financial Crises: \\ THE PROBLEM OF (IN)EXPERIENCE AND REGULATOR EXPERTISE
}

\author{
JOHN CRAWFORD ${ }^{*}$
}

\begin{abstract}
A comprehensive approach to minimizing the long-term costs of financial crises must include efforts to train regulators to respond effectively to crisis dynamics when they arise. An important gap exists, however, in our current approach: a uniquely effective building block for developing crisis-fighting skills is relevant experience, but the infrequency of crises translates to a dearth of opportunities for regulators to attain the necessary experience and develop the pertinent skills. This Article proposes to fill this gap by employing role-playing crisis simulations - or wargames - to create synthetic crisis-fighting experiences. Wargames can provide regulators with a repertoire of crisis experiences that they will have "lived," in a real if attenuated way, which can then aid them in perceiving key patterns and anomalies and in anticipating potential consequences of decisions to intervene (or not) under the intense time pressure and stress of an actual crisis.
\end{abstract}

\footnotetext{
*Associate Professor of Law, University of California, Hastings College of Law. I am grateful for helpful comments and suggestions to Abe Cable, Jared Ellias, Erik Gerding, John Hunt, Zach Price, Morgan Ricks, Jodi Short, Bill Wang, and participants at the National Business Law Scholars Conference, the Bay Area Corporate Law Scholars Workshop, and the UC Hastings Junior Faculty Workshop.
} 
Table of Contents

I. Introduction ...................................................... 113

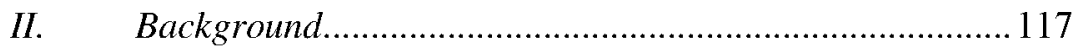

A. The Plausible Scope of Regulator Expertise ............ 117

B. Are Crises Inevitable? .................................... 121

III. The Problem: The Need for Experience and the Scarcity of Opportunities to Attain It........................................ 126

A. When Can Experience Ground Authentic Expertise? 127

B. Loss Propagation Mechanisms and Interventions ...... 131

C. Importance of Experience .................................. 141

D. Effective Intervention in a Complex Environment .... 145

E. Lehman Brothers: A Case Study in the Challenges of Effective Intervention................................... 150

F. Regulator Experience and the 2008 Crisis .............. 157

G. The Difficulty of Getting Experience....................... 160

IV. Manufacturing Experience with Wargames ..................... 161

A. Wargames: Definition and Design .......................161

B. Current Uses and Purposes............................ 167

C. The Power of Wargames .................................. 168

D. Challenges and Obstacles............................... 174

V. Conclusion ................................................... 181 


\section{Introduction}

Financial crises are infrequent but severe. When they hit, their severity can be mitigated by an effective government response. The quality of the government's response depends largely on regulators making good decisions under conditions of intense time pressure and uncertainty. A regulator with expertise rooted in crisis-fighting experience will be better equipped to limit crisis costs. Unhappily for regulator expertise (though happily for the economy), the infrequency of crises means there is a paucity of opportunity to attain relevant experience. This Article explores the possibility of manufacturing experience-based crisis-fighting expertise for regulators and argues that role-playing crisis simulations-or wargames-can provide a uniquely effective way to train them to make better decisions and limit crisis costs in the future.

This inquiry differs markedly from previous analyses of regulators' role in the financial crisis of 2008 and offers prescriptions for the future. Excellent work has been done, for example, on the institutional and individual incentives regulators face, but assumes that if those incentives are properly calibrated and aligned with the public welfare, the ability of regulators to carry out their duties can be taken as given. ${ }^{1}$ Getting incentives right is extremely important, but this Article wrestles with a different question: assuming regulators are properly incentivized, is it even possible for them to get the experience they need to do their job effectively?

Another line of commentary holds that it is futile to rely on regulators to prevent crises; this position often supports arguments that market forces are the best (and perhaps only) tool capable of reining in moral hazard and disciplining the financial system to serve the public interest (if only regulators would get out of the way). ${ }^{2}$ This Article argues that while there almost certainly are areas where reliance on regulatory supervision is futile, in other areas regulators matter immensely. Specifically, relying on regulators to predict the future path of asset prices is likely a fool's errand, but reliance may be entirely justified with respect to two other vital tasks: reducing vulnerabilities in the system prior to a crisis, and taking discrete actions after initial

\footnotetext{
${ }^{1}$ See infra note 29 and accompanying text.

${ }^{2}$ See, e.g., John A. Allison, Market Discipline Beats Regulatory Discipline, 34 CATO J. 345, 345 (2014) ("I can tell you with absolute certainty that market discipline beats regulatory discipline. In fact, . . . regulatory discipline will always fail to reduce volatility and will slow economic growth.").
} 
losses have occurred to prevent them from propagating through the system. This Article's concern is with the lattermost undertaking, and specifically how we might improve regulators' decisions about whether and how to intervene at key junctures in a crisis to try to stop losses from metastasizing.

The task is essential, for a vibrant economy inevitably entails some risk of a crisis. Preparedness must, therefore, augment efforts to rein in risk ex ante. This Article delineates the contours of the crisisrelated tasks for which regulator efficacy is possible and preparedness (therefore) useful. ${ }^{3}$ It identifies loss-propagation dynamics that are persistent across financial crises, and argues that regulators with the appropriate skill set can make reliably better decisions about when and how to intervene to mitigate these dynamics. ${ }^{4}$ It then explains why experience is an important part of developing this skill set. As stated, however, the very infrequency of crises makes attaining the necessary experience a challenge..$^{5}$ The Article proposes wargames as a possible solution to the problem of regulator crisis-fighting inexperience. ${ }^{6}$ It describes wargames as they are used by various organizations, and provides an account of their benefits, along with potential obstacles to their effective use as a training tool.?

Part II begins by explaining the scope of what the Article aims to accomplish and distinguishing its claims from previous work on regulatory efficacy. It then explores the feasibility of preventing crises altogether by reducing risk in the system. Much of the focus of regulators and legal scholars since the crisis has been on reducing systemic risk. ${ }^{8}$ This is appropriate: addressing certain key vulnerabilities, such as excessive leverage, constitutes the most powerful tool we have to lessen crisis costs over the long run. ${ }^{9}$ Further, the crisis revealed areas of great fragility, many of which arguably have yet to be fully addressed. In reforming the system, however, there must come a point beyond which the prophylactic steps to reduce risk are not worth the forgone dynamism and growth. To take an extreme example, outlawing debt could end financial crises, but would be akin to solving the problem of traffic accidents by prohibiting driving. A vibrant

\footnotetext{
${ }^{3}$ See infra Part III.A.

${ }^{4}$ See infra Part III.B.

${ }^{5}$ See infra Part III.G.

${ }^{6}$ See infra Part IV.

${ }^{7}$ See infra Part IV.

${ }^{8}$ See infra note 24 and accompanying text.

${ }^{9}$ See infra text accompanying note 35 .
} 
financial system creates both rewards and risks; we cannot have the first without the second. In the absence of staggeringly costly financial repression, there will always be some risk of crisis-like dynamics arising.

In Part III, I take up two lines of inquiry that frame the scope of what we can realistically expect of regulators in responding to crisis dynamics. First, given the uncertainty surrounding crises, is it even possible to develop expertise in responding to them? Part III.A draws on research from cognitive psychology that shows that skilled intuition (meaning true expertise rooted in experience) is possible only in environments with some stability in the relationship between causes and effects. While I do not question the uncertainty inherent in any financial crisis, nor the futility of relying on regulators (or anyone) to predict all the shocks that could cause a crisis, I argue that once crisis dynamics have arisen, they possess certain persistent structural similarities that can ground authentic expertise. ${ }^{10}$ The structural similarities play out through one or more of a handful of mechanisms by which initial losses can be amplified, causing damage to the real economy potentially orders of magnitude greater than the initial, triggering losses. ${ }^{11}$ Part III.B examines these mechanisms in detail, as well as some of the ways regulators can intervene to try to halt them.

The second line of inquiry, considered in III.C, addresses the question of why experience-as opposed to other types of preparation - is important in developing expertise. Is there something about engaging with the actual oversight of the financial system during a crisis that prepares a regulator for problems more effectively (or at least differently) than, for example, reading the latest academic study? ${ }^{12}$ As in many complex areas, it is possible to articulate valid standards to guide action in a financial crisis, but such standards often do not admit of straightforward application. ${ }^{13}$ Key factual elements necessary to determine how a standard should be applied may be difficult to discern, and a variety of previously unconsidered facts may weigh against the application of a particular standard, or may argue for a modified approach, in a given situation. It would be impracticable to articulate rules for every possible scenario. Exposure to a variety of different scenarios can, however, permit key actors to reason more effectively by

\footnotetext{
${ }^{10}$ See infra Part III.A.2.

${ }^{11}$ See infra Part III.A.2.

${ }^{12}$ See infra text accompanying notes 260-67.

${ }^{13}$ See infra text accompanying notes $279-81$.
} 
analogy in trying to apply standards to the complicated fact patterns of an actual crisis.

Part III.D considers some particular challenges to effective regulatory interventions in a crisis (of the sort discussed in Part III.B), shedding further light on why experience is important for the skillful application of valid guidelines to complicated fact patterns. Part III.E illustrates these challenges in greater depth in the context of a brief case study of the events leading up to the Lehman Brothers bankruptcy. Part III.F briefly considers the experience of regulators in the recent crisis, and Part III.G crystallizes the particular challenge we face in trying to build regulator crisis-fighting expertise: accepting that crisis-fighting expertise can be developed in important part by experience, how can regulators get such experience?

Part IV of the Article proposes wargames as a possible way to manufacture crisis-fighting experience for regulators. Parts IV.A and B define wargames as they are used by the military, other government units, and private parties. The wargames contemplated here are neither board games nor full-fledged field exercises, but "conference-table" games where key players are assigned roles and must respond to crisis scenarios, determining with their decisions the path the wargame narrative takes. Wargames are not entirely new to financial regulators; for example, the Federal Deposit Insurance Corporation ("FDIC") has used wargames to familiarize its staff and other relevant regulators with the contours and constraints of its new Orderly Liquidation Authority ("OLA"), authorized under Title II of the Dodd-Frank Act. ${ }^{14}$ The use of wargames has, however, been limited in both scope and frequency. Wargames are not a systematic part of training top regulators to respond to different possible shocks, and their potential as a research tool and as a training tool for financial regulators has yet to be fully tapped.

Part IV.C explores wargames' potential for training regulators to make better decisions. Wargames, if carried out effectively, give regulators the opportunity to build a repertoire of crisis experiences that they will have "lived," in a real if attenuated way - a repertoire, that is, of fact patterns illustrating plausible cause-and-effect relationships between interventions and outcomes during a crisis, upon which they can draw when facing a real crisis. An additional advantage may arise because a long period without extreme turmoil—perhaps facilitated, in part, by effective governmental responses to crisis-like dynamicsoften creates market and regulatory complacency in the face of

\footnotetext{
${ }^{14}$ See infra notes 236-41 and accompanying text.
} 
excessive risk building in the system. ${ }^{15}$ Wargames could serve as an antidote to such complacency.

Part IV.D considers potential obstacles to wargames' utility in filling the gap of regulator inexperience. Challenges range from the risk of "getting it wrong" (that is, basing wargame scenarios on models that do not map sufficiently closely onto the real world) to regulator inertia or resistance (where, for example, an honest assessment of a wargame would lead to uncomfortable disruptions to the status quo) ${ }^{16}$ These obstacles are not insurmountable, but they do counsel care and caution in the design and implementation of wargames. Part V concludes.

\section{Background}

\section{A. The Plausible Scope of Regulator Expertise}

In exploring what regulators can do to prevent or mitigate damage from crises, it is important to distinguish between a recessionary shock to the economy-for example, an asset bubble bursting - and the ways in which this shock might ripple through the financial system, causing losses to multiply on its way. ${ }^{17}$ Former Federal Reserve Chairman Ben Bernanke provides a useful way of framing the distinction when he compares the aftermaths of two bubbles-housing in the years leading up to the recent crisis, and the dot-com bubble at the turn of the millennium. ${ }^{18}$ The magnitude of stock market losses following the dot-com bust was on the order of $\$ 8$ trillion-even greater than the total peak-to-trough losses (roughly $\$ 7$ trillion) on all U.S. residential real estate from 2006 through $2011 .^{19}$ But the dot-com bust resulted in no financial turmoil and a relatively

\footnotetext{
${ }^{15}$ See infra text accompanying note 273.

${ }^{16}$ See infra Part IV.D.

${ }^{17}$ While this distinction serves valuable heuristic purposes in thinking about the possibilities and limitations of policy and regulation, I should note that I do not mean to make a deep ontological claim here. There may, for example, be some malleability in whether we categorize a particular event as a "trigger" or as a later-falling "domino" in a crisis, depending on the scope and purposes of the particular narrative.

${ }^{18}$ See generally Ben S. Bernanke, Chairman, Bd. of Governors of the Fed. Reserve Sys., Some Reflections on the Crisis and the Policy Response (Apr. 13, 2012), available at http://www.federalreserve.gov/newsevents/ speech/bernanke20120413a.pdf, archived at http://perma.cc/VGF9-HXPS.

${ }^{19} \mathrm{Id}$. at $2-3$.
} 
minor recession. ${ }^{20}$ Why, then, the disproportionate impact of the housing bust? Bernanke's view is that the disparity was due principally to where the losses fell: "In the case of dot-com stocks, losses were spread relatively widely across many types of investors. In contrast, following the housing and mortgage bust, losses were felt disproportionately at key nodes of the financial system . . ."21

These "key nodes"- such as broker-dealers and structured investment vehicles ${ }^{22}$ - tended to be highly leveraged and funded themselves in large part with short-term, run-prone loans. ${ }^{23}$ Both the high leverage and the fact that creditors could withdraw funding on very short notice from systemically important financial institutions contributed to loss-amplifying dynamics.

The loss-amplifying dynamics of the recent crisis will be considered in greater detail in Section III.B, infra; adumbrating the distinction here can, however, help define what is reasonable to expect of regulators, even of those with the greatest intelligence, integrity, and commitment. I am skeptical of regulators' ability to protect the system by predicting and preventing every potential recessionary shock to the economy. Regulators can, however, do two things to make shocks less damaging: (i) ex ante, reduce systemic vulnerabilities on which "shocks" or triggers may work, and (ii) ex post, act to dampen the lossamplification dynamics that arise once a triggering event has occurred. The legal literature since the Crisis has focused largely (though far from exclusively) on the ex ante reduction of vulnerabilities. ${ }^{24}$ Reducing

\footnotetext{
${ }^{20} I d$.

${ }^{21} I d$. at 6.

${ }^{22}$ Id. A structured investment vehicle, or SIV, "is a limited-purpose operating company that ... purchas[es] mostly highly rated medium- and long-term fixed income assets and fund[s] itself with cheaper, mostly short-term, highly rated [commercial paper] and [medium term notes]." GARY B. GORTON, SLAPPED BY THE INVISIBLE HAND: THE PANIC OF 2007, at 106 (2010).

${ }^{23}$ See, e.g., GORTON, supra note 22, at 43-44.

${ }^{24}$ See generally, e.g., Sanjai Bhagat \& Roberta Romano, Reforming Executive Compensation: Focusing and Committing to the Long-term, 26 YALE J. ON REG. 359 (2009) (proposing deferred compensation to ensure financial executives take account of tail risk); Lucian A. Bebchuk \& Holger Spamann, Regulating Bankers' Pay, 98 GEO. L. J. 247 (2010) (proposing a change in executive compensation practices to dampen executives' risk-taking incentives); Morgan Ricks, A Regulatory Design for Monetary Stability, 65 VAND. L. REV. 1289 (2012) [hereinafter Ricks, Regulatory Design] (proposing government insurance of deposit-like "money claims," combined with the extension of risk-constraint regulation to all firms that issue such claims); Mark
} 
systemic vulnerabilities is essential, but, as explained in Section II.B, is unlikely to guarantee the end of crises. The concern of this Article is with what can be done to limit damage once a shock has occurred and crisis-like dynamics have already kicked in-and how regulators may develop the necessary skills to perform well in a crisis.

J. Roe, The Derivatives Market's Payment Priorities as Financial Crisis Accelerator, 63 STAN. L. REV. 539 (2011) (arguing that the repayment priority derivatives counterparties receive in bankruptcy weakens their incentive to monitor financial firms, etiolating market discipline); Richard Squire, Shareholder Opportunism in a World of Risky Debt, 123 HARV. L. REV. 1151 (2010) (calling for regulatory focus on the problem of "correlation-seeking," wherein firms take fees for assuming contingent debts whose triggers correlate with the firms' own insolvency risks); Anat R. Admati et al., Fallacies, Irrelevant Facts, and Myths in the Discussion of Capital Regulation: Why Bank Equity is Not Socially Expensive (Oct. 22, 2013) (unpublished manuscript), available at_http://www.gsb.stanford.edu/sites/default/files/ research/documents/Fallacies\%20Nov\%201.pdf, archived at http://perma.cc/ 77K9-TDP4 (arguing for heightened capital requirements as a way to lessen the risk and costs of bank insolvency). Mehrsa Baradaran has recently written on regulatory efforts to target and address weaknesses in the financial system by constructing hypotheticals, particularly through the stress tests and living wills prescribed by the Dodd-Frank Act. See Mehrsa Baradaran, Regulation by Hypothetical, 67 VAND. L. REV. 1247 (2014). She suggests that supplementing current efforts with financial wargames may address shortcomings in the current approach. Id. While Baradaran's focus on addressing weaknesses ex ante is consistent with the use of wargames advocated here, my concern is more with developing regulator expertise in crisis response than with wargames' ability (or inability) to predict future shocks or expose hitherto unperceived vulnerabilities.

The literature on financial crisis response rather than prevention has had two primary areas of focus. The first involves mechanisms to try to ensure the automatic injection of necessary capital into wobbly banks in a crisis. See generally, e.g., Jeffrey N. Gordon \& Christopher Muller, Confronting Financial Crisis: Dodd-Frank's Dangers and the Case for a Systemic Emergency Insurance Fund, 28 YALE J. ON REG. 151 (2011) (proposing a trillion-dollar insurance fund to inject capital into financial firms in the throes of a systemic crisis). The second is the resolution of insolvent financial firms. See, e.g., Morgan Ricks, Regulating Money Creation After the Crisis, 1 HARV. Bus. L. REV. 75, 122-29 (2011) [hereinafter Ricks, Regulating Money Creation] (providing a negative assessment of the crisis-prevention potential of the OLA created under the Dodd-Frank Act); Arthur E. Wilmarth, Jr., Reforming Financial Regulation to Address the Too-Big-to-Fail Problem, 35 BROOK. J. INT'L L. 707, 754-57 (2010) (laying out the criteria for an effective resolution regime). 
While there has been less academic work on regulatory responses to crises, as opposed to efforts to prevent them, there is a rich literature on the factors that affect regulator performance more generally. ${ }^{25}$ This Article complements that literature by focusing specifically on the importance of experience in the development of regulator skills. Experience has been understood as an essential ingredient of regulator expertise at least since the New Deal, ${ }^{26}$ but it is generally taken for granted that regulators will have the opportunity to attain the relevant experience in the course of their duties (or, perhaps, prior thereto) ${ }^{27}$-an assumption that is likely justified in many or most instances. ${ }^{28}$

The literature on financial regulators in the wake of the crisis, as well as a few actual reforms affecting front-line regulators, has focused principally on regulators' incentives to be diligent, critical, proactive, and honest, rather than on expertise per se. ${ }^{29}$ Getting

${ }^{25}$ See generally, e.g., M. Todd Henderson \& Frederick Tung, Pay for Regulator Performance, 85 S. CAL. L. REV. 1003 (2012) (suggesting that performance-based pay for financial regulators could improve regulatory oversight).

${ }^{26}$ See, e.g., Reuel E. Schiller, The Era of Deference: Courts, Expertise, and the Emergence of New Deal Administrative Law, 106 MiCH. L. REV. 399, 433 (2007). In a typical passage, for example, the Supreme Court stated,

In [upholding a particular unfair trade practice] we give great weight to the Commission's conclusion, as this Court has done in other cases .... [T] $[$ he Court [has] called attention to the express intention of Congress to create an agency whose membership would at all times be experienced, so that its conclusions would be the result of an expertness coming from experience ....

Id. at 433 (quoting FTC v. Cement Inst., 333 U.S. 683, 720 (1948) (alterations in original)).

27 The political science literature on regulator and agency expertise has, for example, tended either to assume expertise as an exogenous variable, or to build it into a model as an endogenous variable (depending, for example, on the scope of agency discretion vis-à-vis the legislature), but under the assumption that developing expertise is a straightforward function of effort (or investment of time and other resources). See, e.g., Matthew C. Stephenson, Bureaucratic Decision Costs and Endogenous Agency Expertise, $23 \mathrm{~J} . \mathrm{L}$. ECON. \& ORG. 469, 470 (2007).

${ }^{28}$ Casual empiricism suggests that most essential tasks of most regulators are persistent or regularly recurring parts of their jobs.

${ }^{29}$ See generally, e.g., Henderson \& Tung, supra note 25 (proposing compensating regulators with subordinated debt of the firms they regulate, so that they internalize the costs of the downside risk these firms are taking and 
incentives right is critically important. This Article, however, deals with a different question: assuming financial regulators' incentives are appropriately aligned with the public and the legislature, how can we ensure that they are prepared to carry out the tasks we ask of them $?^{30}$

\section{B. Are Crises Inevitable?}

One might wonder why preparing regulators to deal with crises is worth the trouble; wouldn't it be more effective simply to eliminate the risk of crises altogether? There are at least three (overlapping) ways regulators might try to eliminate the risk of a crisis. First, they could try to prevent shocks or triggers from occurring in the first place. ${ }^{31}$ While

assume a more proactive role in resolving problems and constraining risk); Brett McDonnell \& Daniel Schwarcz, Regulatory Contrarians, 89 N.C. L. REV. 1629, 1632-33 (2011) (arguing for greater use of "regulatory contrarians," which they define as "entit[ies] that [are] affiliated with, but independent of, a financial regulator with the task of monitoring that regulator and the regulated marketplace and publicly suggesting new initiatives or potential structural or personnel changes"); Saule T. Omarova, Bankers, Bureaucrats, and Guardians: Toward Tripartism in Financial Services Regulation, 37 J. CORP. L. 621 (2012) (questioning whether regulators under the current structure can adequately represent the public interest, and suggesting that a "Public Interest Council" should be established to serve this end). Note as well that the Office of the Comptroller of the Currency-the chief regulator for nationally chartered banks-has recently instituted a stricter system of review for its examiners, with a view to holding them accountable for their failures in oversight. See Michael R. Crittenden, Bank Examiners to Face Rigorous Reviews, WALL ST. J., Sept. 29, 2013, at C5. The (very reasonable) implicit assumption seems to be that regulators will do better if they face more direct consequences for failing to do a good job.

30 See ERIK F. Gerding, Law, Bubbles, and Financial Regulation 500 (2014) (" $[R]$ ecognizing that financial regulators are members of a profession that requires intellectual resources and strategic foresight-and not a mere bureaucracy that demands the occasional stick or carrot—can do much to ensure that regulators faithfully and competently execute their responsibilities ...."). Gerding points to the military's and foreign service's efforts to "cultivate norms and develop intellectual capital," making use of institutions such as "in-house graduate schools (such as war colleges), policy planning arms, and think tanks," as well as by exposing personnel to foreign counterpart personnel and institutions. Id. at 498-99.

${ }^{31}$ See, e.g., Erik F. Gerding, Laws Against Bubbles: An Experimental-AssetMarket Approach to Analyzing Financial Regulation, 2007 WIS. L. REV. 977, 1006-36 (2007) (outlining different legal approaches to preventing asset 
regulators should certainly be alive to potential triggers, and prevent them to the degree possible, ${ }^{32}$ it would be foolhardy to rely on regulators to foresee and forestall every possible shock. Consider in this respect that while we may be very alive to the risk of a housing bubble today, the next trigger might be a different asset bubble going "pop!", or the default of a foreign sovereign, or a cyber-attack on the US financial system, or a natural disaster, or -if the system is sufficiently vulnerable-a little boy yelling (as in Mary Poppins) "give me back my money!", 33 and so on. ${ }^{34}$

bubbles from developing, and concluding that the effectiveness of such methods for eliminating bubbles is likely weak).

${ }^{32}$ See Gerding, supra note 30, at 47-48 (citing economic research on early "warning signs" of bubbles, including "cheap credit," "high[] leverage," "a surge of external capital flowing into a country," and "an influx of inexperienced investors into a market"). Indeed, it would be irresponsible for financial regulators not to keep their eyes peeled for potential signs of overheating in different asset markets, and regulators do, in fact, keep watch for such signs. See, e.g., Jon Hilsenrath \& Victoria McGrane, Fed Eyes Bubble Risks, Minutes Show, WALl ST. J., Jan. 9, 2014, at A1.

${ }^{33}$ MARY POPPINS (Walt Disney Productions 1964). In the movie, young Michael Banks goes to visit his father's bank, and some of the bank employees try to convince him to put his money (tuppence) into a savings account. Id. When they take the tuppence from him, he yells "Give it back! Give me back my money!" Id. Other customers in the bank hear him and panic, thinking that the bank is unable to meet a withdrawal demand. Id. Thus starts a run on the bank. Id. The reference is not entirely whimsical; the possibility of a bank run starting not because of legitimate news about the actual condition of the bank, but rather because of depositor fears of others running on the bank-making a run a self-fulfilling prophecy - has been famously modeled by Diamond and Dybvig. Douglas W. Diamond \& Philip H. Dybvig, Bank Runs, Deposit Insurance, and Liquidity, $91 \mathrm{~J}$. POL. ECON. 401, 410 (1983) ("The problem is that once [depositors] have deposited, any thing that causes them to anticipate a run will lead to a run.").

${ }^{34}$ Trying to predict the source of the next crisis is where the problem of "black swans" looms largest. Nassim Nicholas TAleb, The Black Swan: THE IMPACT OF THE Highly IMPROBABLE, at xvii (2007). As defined by Nicholas Taleb, a black swan is an extreme event that does not accord with previous patterns of experience. Id. Again, even if black swans are inherently unpredictable-which implies that it is impossible to get better at anticipating them-I argue that the ability to respond to the specific loss propagation dynamics a black swan could trigger in the financial system is an activity at which regulators can improve. It is also important to remember that even if one may not be able to predict exactly what will cause a phase transition into panic 
A second way to try to prevent crises is to eliminate vulnerabilities in the system. ${ }^{35}$ Mitigating vulnerabilities is an

mode, there are likely reliable signs that the system is more or less vulnerable to such a transition. See GERDING, supra note 30, at 47-48.

Among the reasons it is so difficult to foretell exactly where and when a tipping point into crisis will occur is the phenomenon of nonlinearity. This refers to systems where the "inputs" are not (necessarily) proportional to the "outputs." See Nonlinearity, INVESTOPEDIA, http://www.investopedia.com/ terms/n/nonlinearity.asp (last visited Oct. 17, 2014), archived at http://perma.cc/UQ25-SYMU (defining nonlinearity as "[a] relationship which cannot be explained as a linear combination of its variable inputs"). Even if such a system is deterministic and follows relatively simple laws, immeasurably small differences in initial conditions can lead to large differences in outcomes. See id. The most famous example is Edward Lorenz's "butterfly effect." Edward N. Lorenz, Predictability; Does the Flap of a Butterfly's Wings in Brazil Set Off a Tornado in Texas? (Dec. 29, 1972), available at http://eaps4.mit.edu/research/Lorenz/Butterfly_1972.pdf, archived at http://perma.cc/9587-HX27 ("If a single flap of a butterfly's wings can be instrumental in generating a tornado, so also can ... the activities of innumerable more powerful creatures, including our own species."). Alan Beyerchen provides a lucid explanation of the logic and import of Lorenz's work:

Edward Lorenz set up three linked first-order differential equations in a computer model of weather development. With certain parameters, the system proved so sensitive to the initial conditions that it was estimated that quite literally a butterfly flapping its wings in one part of the world would be sufficient to cause a major storm to emerge somewhere else. An arbitrarily small change could generate an entirely different history for the system.

Alan Beyerchen, Clausewitz, Non-linearity, and the Unpredictability of War, 17 INT'L SECURITY 59, 66 (1992).

The butterfly effect arises from a "complex adaptive system[]"- that is, a system "comprised of a macroscopic, heterogeneous set of autonomous agents interacting and adapting in response to one another and to external environment inputs." J.B. Ruhl, Law's Complexity: A Primer, 24 GA. ST. U. L. REV. 885, 887 (2008). For a good description of how the theory of these systems applies to the financial system, see generally Robert M. May et al., Ecology for Bankers, 451 NATURE 893 (2008).

${ }^{35}$ This could, of course, have the effect of preventing certain sorts of bubbles from popping in the first place, thus overlapping with the first method described directly above. There are nonetheless two reasons that it is worth treating the approaches as distinct. First, bubbles popping are not the only plausible trigger for a crisis (think again of a cyber-attack or an oil supply shock). See Terry Macalister, Background: What Caused the 1970s Oil Price 
extremely important regulatory task; the question is whether all vulnerabilities could be wrung out of the system. I will venture here that they could be, if we were willing to bear the cost. We are not, however, willing to do so. We could, for example, require all financial intermediaries to fund themselves entirely with equity, and force those desiring the money storage and transaction processing services of a bank account to use "currency warehouses" with 100 percent reserve requirements. ${ }^{36}$ This would eliminate bank runs and the lossamplification mechanisms described below, but would entail staggering costs, as the funds people and businesses reserve for near-term transactional purposes would then be unavailable to be lent out to creditworthy consumers or job-creating businesses. ${ }^{37}$ There is, then, a trade-off involved in setting and enforcing risk-constraint measures. Financial stability is clearly desirable, but as Gary Gorton notes, really eliminating any risk of crisis could impose unacceptable costs. ${ }^{38}$

The great "Quiet Period" in American finance 39 -the period between the 1930s and the recent crisis, during which there were no system-wide panics or runs on the financial system-may suggest a third way to prevent (most of) the destructive dynamics of a financial crisis. A sine qua non of the Quiet Period was the institution of federal deposit insurance for bank accounts. ${ }^{40}$

Shock?, GUARDIAN (Mar. 3, 2011, 11:26 AM), http://www.theguardian.com/ environment/2011/mar/03/1970s-oil-price-shock, archived at http://perma.cc/ TN86-NCRM (discussing how an oil embargo triggered an economic crisis). Second, it is possible to allow speculation that feeds a bubble without risking a financial crisis if, as with dot-com stocks, losses fall on shareholders rather than (short-term) creditors. See Kenneth S. Rogoff, Sovereign Debt in the Second Great Contraction: Is This Time Different?, NAT'L BUREAU OF ECON. RESEARCH REP., no. 3, 2011 at 2.

${ }^{36}$ See Ricks, Regulating Money Creation, supra note 24, at 98 n.55.

${ }^{37}$ Id. at 100 .

38 Gary B. Gorton, Misunderstanding FinanCial Crises: Why We DON'T SEE THEM COMING 177-78 (2012) ("We could design a financial system that avoids crises, for a period of time at least, but the design faces the problem of risking a crisis on the one hand or being financially repressive on the other. .. If a policymaker, whose goal is to maximize GDP growth, could choose whether to have periodic crises or not, the policymaker might choose to have crises rather than to have low growth. It depends how society feels about economic volatility.").

${ }^{39}$ GORTON, supra note 22, at 11.

${ }^{40}$ Ricks, Regulating Money Creation, supra note 24, at 119. Deposit insurance was not the sole cause of the Quiet Period; as Gary Gorton has noted, other key 
In the decades leading up to the recent crisis, however, banklike functions had migrated increasingly to institutions outside the umbrella of deposit insurance and traditional bank regulation-the "shadow banking" system. For example, instead of a bank using funds from deposits to make (and hold) a mortgage loan, a broker-dealer might hold a mortgage-backed security and use it as collateral for a short-term loan. ${ }^{41}$ These short-term loans often have a maturity of just one day, but in normal times are routinely rolled over. ${ }^{42}$ The institutional investors that make such loans can withdraw funding rapidly, thus functioning very much like depositors before the creation of the Federal Deposit Insurance Corporation. ${ }^{43}$

The most acute phases of the recent crisis involved runs on "shadow banks." Perhaps we could prevent many, if not all, of the lossamplifying mechanisms described in Part III.B, infra, if we extended federal guarantees to the shadow banking system on a permanent basis. ${ }^{44}$ But this would create significant moral hazard issues. Various risk-constraint regulations and supervision might limit the moral hazard costs to acceptable levels, but it is worth noting that one of the principal measures to counter moral hazard in the context of federal deposit

factors include "the 'stick' of bank regulations and examinations" as well as "the 'carrot,' ... of monopoly rents that made the charter valuable." GORTON, supra note 22 , at 54.

${ }^{41}$ See Tobias Adrian Et Al., Fed. Reserve Bank OF N.Y., Staff RePORT No. 529, REPO AND SECURITIES LENDING 2 (2013), available at http://www.newyorkfed.org/research/staff_reports/sr529.pdf, archived at http://perma.cc/99D5-QCJM.

${ }^{42}$ The most typical such day-to-day loan is the sale and repurchase agreement, or "repo" loan. See id. at 4.

${ }^{43}$ See id.

44 The U.S. government's response to the crisis in 2008 involved temporarily extending its guarantees to large swaths of the shadow banking system. See infra note 76 and accompanying text. For proposals to extend the government guarantees more broadly on a permanent basis, see, e.g., Ricks, Regulatory Design, supra note 24, at 1290, 1343-54; Ricardo J. Caballero, The "Other" Imbalance and the Financial Crisis 37 (Nat'l Bureau of Econ. Research, Working Paper No. 15636, Jan. 2010), available at http://www.nber.org/ papers/w15636.pdf, archived at http://perma.cc/QF7U-TUTH ("One approach to deal with this dual problem-the shortage of safe assets and the financial fragility created by the private sector's solutions to it-is for governments around the world [sic] explicitly absorb a larger share of the systemic risk (and be compensated for it). This approach would include modifying their portfolios and becoming the provider of insurance of last resort, and not just the lender of last resort, for widespread panics."). 
insurance - caps on the insurable amount in each account-would be difficult to apply to the shadow banking system, where the rise in recent decades of gargantuan asset pools has meant that institutions regularly wish to park enormous sums in "safe," deposit-like accounts. ${ }^{45}$ In any event, the toxic political and public reaction to the bailouts of Wall Street during the recent crisis make it unlikely that such guarantees will be implemented any time soon. History tells us that when the activities of banks or shadow banks lack credible insurance, crises tend to recur every couple of decades or so. ${ }^{46}$ With the rise of uninsured deposit-like claims in the shadow banking sector, there is thus reason to take steps to prepare for crises.

\section{The Problem: The Need for Experience and the Scarcity of Opportunities to Attain It}

This Section reviews research in cognitive psychology on when expert decision-making (in any domain) is feasible, and identifies structural features that are persistent across financial crises and that can ground true expert decision-making. It then explains why experience is important to developing relevant expertise. It explores some challenges to effective intervention-illustrating why the context-sensitivity that experience builds can be vital to developing decision-making skillsand paints a brief picture of the Lehman Brothers failure in light of these challenges. Finally, against this backdrop, it explains the gap in our current scheme: the difficulty of attaining relevant experience.

\footnotetext{
${ }^{45}$ See, e.g., Zoltan Pozsar, Institutional Cash Pools and the Triffin Dilemma of the U.S. Banking System 4-5 (Int'l Monetary Fund, Working Paper No. 11/190, 2011), available at https://www.imf.org/external/pubs/ft/wp/ 2011/wp11190.pdf, archived at http://perma.cc/YUZ4-N8W6 (explaining that "institutional cash pool[s]"- defined as "large, centrally managed short-term cash balances of global non-financial corporations and institutional investors"-climbed from approximately $\$ 100$ billion in 1990 to over $\$ 2.2$ trillion in 2007, and hovered, post-crisis, at $\$ 1.9$ trillion in 2010).

${ }^{46}$ See Ben Bernanke, The Federal Reserve and the FinanCial Crisis 910 (2013) (identifying six banking panics between 1873 and 1914); GORTON, supra note 38, at 29 (quoting THEODORE GILMAN, FEDERAL ClEARING HOUSES 183 (1899)) ("Since 1793 [financial] panics have occurred [in the United States] in the following years: 1797, 1811, 1813, 1816, 1819, 1825, $1837,1847,1857,1866,1873,1884,1890$, and 1893.").
} 


\section{A. When Can Experience Ground Authentic Expertise?}

There are a number of areas in which the judgments of recognized experts are not reliably correct; their expertise is, to a certain extent, illusory. ${ }^{47} \mathrm{I}$ aim in this Section to defend the possibility of expertise, and specifically intuitive (i.e., experience-based) expertise, in the context of financial regulation and crisis-fighting.

\section{Conditions for Intuitive Expertise}

Daniel Kahneman (among others) has documented a variety of contexts in which self-styled experts' predictive skills and judgment wind up being no better than a novice's. ${ }^{48}$ A classic case is the stock picker. ${ }^{49}$ Stock pickers might know a great deal about the stock market and about the businesses of the individual companies whose stocks they're betting on. ${ }^{50}$ However, their ability to predict whether a given company's (risk-adjusted) stock returns will beat or lag the market over any time period, absent inside information, is usually no better than the proverbial dart-throwing chimpanzee-despite the fact that they may have very high subjective confidence in their own judgment. ${ }^{51}$

\footnotetext{
${ }^{47}$ See, e.g., GARY KLEIN, SOURCES OF POWER 280-82 (1998) (contrasting skilled intuition with "superstition"). There are different views on which domains admit of authentic expertise:

At one extreme is the work of Ericsson and Charness (1994), suggesting almost anyone can become expert at almost anything, given enough practice. At the other extreme is the work of people like Russo and Shoemaker, suggesting that all of us are inherently biased and unreliable as decision makers. And in between is the suggestion by Shanteau that expertise is more easily acquired in some domains than others.

Id. at 282.

${ }^{48}$ See Daniel KahNEMAN, ThinkING, Fast AND SlOW 212-21 (2011).

${ }^{49} I d$. at $212-16$.

${ }^{50} I d$.

${ }^{51} I d$. at 214 ("F]ew stock pickers, if any, have the skill needed to beat the market consistently, year after year. Professional investors, including fund managers, fail a basic test of skill: persistent achievement."). The idea that individual investors cannot reliably beat the market is an implication of the "efficient markets model." See generally Eugene F. Fama, Efficient Capital Markets: A Review of Theory and Empirical Work, 25 J. FIN. 383 (1970). Most financial economists today view market efficiency as a relative concept, and
} 
Gary Klein, on the other hand, has spent his career studying and explaining cases in which experts' intuitive judgments are reliably better than a novice's (and emphasizing the key role of experience). ${ }^{52}$ For example, extensive research on chess masters shows that their advantage over less-skilled players lies not in deliberation but in intuition." "Most of what differentiates skilled from unskilled chess players," studies have shown, "is their tacit knowledge, not their ability to calculate move quality." ability to do deliberate search and analysis doesn't seem to get any better." ",55 Another example is a "fireground commander," responsible for coordinating and directing a fire fighting team's activities in fighting a blaze. ${ }^{56}$ There are extensive guidelines for fighting fires, but veterans can draw on a repertoire of experiences and fact patterns that aid them in making better decisions than a novice could in applying (or departing from) general guidelines in specific contexts. ${ }^{57}$

measure it by the speed with which market prices incorporate new information. Larry Swedroe, The Impact of News Events on Market Prices, CBS MONEYWATCH (Oct. 17, 2013, 7:37 AM), http://www.cbsnews.com/news/theimpact-of-news-events-on-market-prices/, archived at http://perma.cc/UVX9TJYU. The literature on market inefficiencies is vast; for a good introduction to some of this literature aimed at a legal audience, see generally William K.S. Wang, Some Arguments That the Stock Market is Not Efficient, 19 U.C. DAVIS L. REV. 341 (1986). It is also widely accepted that markets cannot, in fact, be perfectly efficient, where perfect efficiency implies that reliable supernormal profits are impossible. See Sanford J. Grossman \& Joseph E. Stiglitz, On the Impossibility of Informationally Efficient Markets, 70 AM. ECON. REV. 393, 393 (1980). This is because the arbitrageurs whose activities ensure new information is impounded into market prices must see some (reliable) profit in their work in order to incur the cost of the activities in the first place. Id. Hence, there must be an "equilibrium degree of disequilibrium" even in highly efficient markets. Id.

${ }^{52}$ See generally GaRY KLeIN, STREeTlightS AND SHAdOWS (2011).

${ }^{53} \mathrm{Id}$. at 73 .

${ }^{54} I d$.

${ }^{55}$ Id. (citing Bruce D. Burns, The Effects of Speed on Skilled Chess Performance, 15 PsYCHOL. SCI. 442 (2004); see also Roberta Calderwood et al., Time Pressure, Skill, and Move Quality in Chess, 101 AM. J. PsYCH. 481, 481 (1988).

${ }^{56}$ See Daniel Kahneman \& Gary Klein, Conditions for Intuitive Expertise: A Failure to Disagree, 64 AM. PSYCHOLOGIST 515, 516 (2009).

${ }^{57} I d$. ("[Fireground commanders] could draw on the repertoire of patterns that they had compiled during more than a decade of both real and virtual experience . . . to anticipate how flames were likely to spread through a 
So who is right? Should we trust the intuitive judgments of experts or not? If some self-styled experts do have superior discernment and others do not, how can we determine which is which? Kahneman and Klein, coming from (often bitterly) opposed camps within cognitive psychology, decided to try to identify their specific disagreements and wound up co-authoring a paper entitled Conditions for Intuitive Expertise: A Failure To Disagree. ${ }^{58}$ In it, they agree that in some areas, expertise is illusory, while in others, it is very real. ${ }^{59}$ (Sometimes, they note, the same person has both illusory and real expertise, or "fractionated expertise.") ${ }^{60}$ They also agree that the expert's own subjective confidence in his judgment is worthless as a guide to when we can trust expertise and when we cannot. ${ }^{61}$

What, then, determines whether an expert's intuitive judgment is reliable or not? Kahneman and Klein identify three conditions. ${ }^{62}$ First, there must be "validity" to the environment in which the experts operate. ${ }^{63}$ This means that there must be some constancy between objectively identifiable cues and subsequent events-some stable cause-effect relationships that we can observe. ${ }^{64}$ This is not, they hasten to add, incompatible with a large degree of uncertainty in an environment. ${ }^{65}$ They point to warfare and poker as two areas where there is a significant degree of uncertainty, but wherein there are better moves and worse moves, and making the better moves reliably increases one's chances of winning. ${ }^{66}$

Assuming there is some stability in the environment, there are two further requirements for experts to be able to develop reliable

building, to notice signs that a house was likely to collapse, to judge when to call for additional support, and to make many other critical decisions.").

${ }^{58}$ See generally id.

${ }^{59} \mathrm{Id}$. at 522 ("For example, auditors who have expertise in 'hard' data such as accounts receivable may do much less well with 'soft' data such as indications of fraud.") (citation omitted).

${ }^{60} I d$.

${ }^{61} I d$. at 523.

${ }^{62}$ See infra notes $63-67$ and accompanying text.

${ }^{63}$ Kahneman \& Klein, supra note 56, at 519.

${ }^{64} \mathrm{Id}$. at 520 .

${ }^{65} I d$. at 524 .

${ }^{66} I d$. 
intuitive judgments: they must have a chance to practice, and they must have a chance to receive and process feedback. ${ }^{67}$

The first question we must address, then, is whether the financial system is the type of valid environment that would permit experts to learn to anticipate or predict outcomes from currently observable variables and possible regulatory actions.

\section{Are Financial Crises Examples of "Valid Environments"?}

Here again one must distinguish between crisis triggers, on the one hand, and the mechanisms within the financial system that can amplify initial investment losses and (greatly) exacerbate damage to the real economy. ${ }^{68}$ In his memoirs, Hank Paulson recounts a 2006 conversation he had with President Bush that captures just this distinction between crisis triggers and the sorts of problems that regulators must respond to once the crisis arises:

"We can't predict when the next crisis will come," I said. "But we need to be prepared."

In response to a question of the president's, I said it was impossible to know what might trigger a big disruption. Using the analogy of a forest fire, I said it mattered less how the blaze started than it did to be prepared to contain it - and then put it out.

I was right to be on my guard, but I misread the cause, and the scale, of the coming disaster. Notably absent from my presentation was any mention of problems in housing or mortgages. ${ }^{69}$

Consistent with Paulson's account, I am (again) skeptical that the macroeconomy provides the sort of valid environment that would ground expertise in predicting where the next shock will come from. There is good reason to believe, however, that once crisis dynamics

\footnotetext{
${ }^{67} I d$. ("Other necessary conditions include adequate opportunities for learning the environment (prolonged practice and feedback that is both rapid and unequivocal).").

${ }^{68}$ See supra note 24 and accompanying text.

${ }^{69}$ Henry M. Paulson, JR., ON THE BrinK: Inside the RaCe to Stop the Collapse of the Global Financial System 47 (2010). Paulson's initial concern was with derivatives. $I d$. at 46.
} 
emerge, whatever their trigger, there is some validity to the environment.

Just as in war, of course, validity does not imply that the structure of a crisis is immediately clear. In his memoirs, Timothy Geithner speaks of the "inevitable fog of diagnosis" as a vulnerable system begins to experience problems, and the difficulty of trying to determine "whether the initial market turmoil is a healthy adjustment or the start of a systemic meltdown, a precursor to a modest economic slowdown or something much worse." ${ }^{70}$ Nevertheless, in explaining why he wrote his memoirs, Geithner states "[a]ll financial crises are different, but they have a lot in common, and there are lessons to learn from this extreme one that can help policymakers and the public during the next one." $" 1$

Even as the particular institutional details may vary, then, and even as real-time news and data require extensive interpretation through the fog of uncertainty, there are structural similarities across crises. These include capital holes at-and massive withdrawals of cash from-key financial intermediaries, leading to the loss amplification and contagion dynamics described below. Assessing and responding to these dynamics constitute activities which, I argue, despite all their uncertainties, can be carried out reliably better or worse.

In summary, the concern of this Article is not with bubbles or shock prevention, but rather with the possibility of short-circuiting the loss-propagation mechanisms that result from contagion and panics among creditors of crippled financial institutions. Whether the next shock is from a bubble bursting or from something else, the point is to be prepared not to let loss propagation mechanisms kick into high gear.

\section{B. Loss Propagation Mechanisms and Interventions}

If financial crises do provide the sort of valid environment that permits reliably better and worse choices by regulators, then we must be able to explain where the validity lies - i.e., where (conditional) predictability exists as to how losses work their way through the system. We must, in other words, be able to outline some of the basic processes of loss propagation, as well as the sorts of interventions that can dampen this dynamic. In this Section, I briefly outline some of these mechanisms and interventions, with a brief nod to the steps

${ }^{70}$ Timothy F. Geithner, Stress Test: Reflections on FinanCial Crises $119-20$ (2014).

${ }^{71} I d$. at 21 . 
regulators actually took along these lines during the recent crisis. ${ }^{72}$ For clarity's sake, the presentation here may make the mechanisms seem more linear and cut-and-dried than they usually appear to be when, for example, regulators are struggling to determine whether the market is experiencing a containable market correction, or the harbingers of panic. It is important to emphasize, then, that even if these mechanisms are similar enough across crises to reward experience, addressing them is far from straightforward. ${ }^{73}$

It is also worth emphasizing at the start that the enumeration of interventions is meant to be illustrative rather than exhaustive, and their division here is somewhat artificial and arbitrary. The intense interaction among the mechanisms and the firms on which they operate means that almost any of the interventions described could contribute to counteracting all of the mechanisms.

Finally, it is important to stress that none of the regulatory interventions described here are cost-free. The costs include potential direct losses to taxpayers in the event of a bailout, and losses arising from moral hazard and the inefficient decisions that it can enable. Of course, the costs and benefits of each type of move are highly contextdependent. As I will argue in Section III.C, infra, this very contextdependence makes experience important for those making the intervention decisions. Part III.D, infra, discusses the costs in greater detail.

What follows, then, are some of the ways in which financial crises wreak havoc, and some of the ways regulators can try to limit their destruction.

\footnotetext{
${ }^{72}$ It is important to note that not all of the tools discussed in this Section remain in the regulators' toolkits at present. Perhaps most obviously, direct capital injections would require congressional action, as it did in September and October of 2008. See Ricks, Regulating Money Creation, supra note 24, at 135. Furthermore, the blanket guarantees that the Treasury Department provided for the money market fund industry and that the Federal Deposit Insurance Corporation provided for uninsured bank debt-neither of which required congressional action in 2008-would require such action today. See $i d$. at 132-33 (explaining how legal authorities used to establish the guarantees for banks and money market funds were removed, respectively, by the DoddFrank Act and the Economic Emergency Stabilization Act).

${ }^{73}$ Part III.C, infra, will explain in greater deal why, even if we understand the basic dynamics of a problem and can articulate guidelines for solving them, experience is still essential for knowing how to apply the guidelines in complex situations full of curveballs and surprises.
} 


\section{Credit Crunch}

As financial intermediaries suffer losses, their capital position deteriorates; in other words, they eat through their equity cushion and risk balance sheet insolvency. In order to rebuild their capital, they may either raise more equity capital or they may sell assets to pay off debts-effectively shrinking their balance sheets. ${ }^{74}$ In a crisis, there are good theoretical and empirical reasons to believe banks tend more toward the latter strategy of "asset shrinkage.",75

More generally, weakened financial institutions tend to shy from new lending, and failed banks, of course, stop lending altogether. This can significantly damage the economy if other financial institutions are unable to fill the gap in the near-term, either because they too are in a process of retrenchment, or because they lack the sector-specific or geographic expertise to exploit the opening. When a large number of institutions face this kind of pressure, creditworthy consumers and job-creating businesses have a harder time getting loans, exacerbating recessionary dynamics in the real economy. ${ }^{76}$

The most obvious (and radical) tool to counteract a credit crunch is to inject capital directly into banks. This is what regulators did after Congress passed the Emergency Economic Stabilization Act in October 2008, with its authorization of the Troubled Asset Relief Program ("TARP"). ${ }^{77}$ If far enough ahead of the curve, of course,

${ }^{74}$ Anil K. Kashyap et al., Rethinking Capital Regulation, in MAINTAINING STABILITY IN A CHANGING FINANCIAL SySTEM 431, 439-40 (2008), available at http://www.kansascityfed.org/publicat/sympos/2008/KashyapRajanStein. 03.12.09.pdf, archived at http://perma.cc/9BNJ-ZXZP.

${ }^{75}$ See Kashyap et al., supra note 74; Anat R. Admati et al., Debt Overhang and Capital Regulation 11-13 (Mar. 23, 2012) (unpublished manuscript), available at http://www.gsb.stanford.edu/sites/default/files/research/documents/ AdmatiDebt032612.pdf, archived at http://perma.cc/PH6F-NWB9 (examining the different conditions under which shareholders would have incentives to increase capital ratios via selling off assets as opposed to raising new equity).

${ }^{76}$ See Ben S. Bernanke, Nonmonetary Effects of the Financial Crisis in the Propagation of the Great Depression, 73 AM. ECON. REV. 257, 257 (1983).

${ }^{77}$ The Treasury Department's original plan was to purchase troubled assets from large banks with TARP funds, but this approach was quickly jettisoned and capital was injected directly into banks instead. See generally John M. Brandow et al., Davis Polk \& Wardwell LLP, The Capital Twist, in FINANCIAL CRisis Manual: A GUIDE to the Laws, Regulations and Contracts of THE FINANCIAL CRISIS 67 (2009). 
regulators can try to use regulatory powers ${ }^{78}$ or moral suasion to force or encourage financial firms to retain earnings or raise capital in private markets.

\section{Monetary Contraction}

Financial institutions often issue very short-term debt that their claimants hold as part of their "transaction reserve"-i.e., the assets the claimant uses to meet its near-term transactional needs, whether it be paying employees or purchasing supplies for a business, or paying rent and buying groceries in the case of individuals. ${ }^{79}$ These assets in a claimant's transaction reserve can either themselves serve as the medium of exchange, or be exchangeable for the "medium of exchange immediately at virtually no cost." ${ }^{\text {"80 }}$ In this respect, a financial institution's short-term debt can sometimes function as the equivalent of money for those who hold it. ${ }^{81}$ If an institution's debt is not insured, its failure would make something that was money-like-highly liquid and with an extremely stable price-into a non-money-like claim, i.e., something much harder to monetize or sell, and with a price that fluctuates relative to currency. ${ }^{82}$

Bank failures, then, can lead to a contraction in the money supply. ${ }^{83}$ The principal cause of the Great Depression is today widely understood to have been such a monetary contraction, which led to debilitating deflation. ${ }^{84}$ The Federal Reserve can counteract monetary

\footnotetext{
${ }^{78}$ The Federal Reserve, for example, can restrict capital distributions by systemically important financial institutions based on how well they fair in annual stress tests required under Dodd-Frank. See, e.g., Press Release, Bd. of Governors of the Fed. Reserve Sys. (Nov. 1, 2013), available at http://www.federalreserve.gov/newsevents/press/bcreg/20131101a.htm, archived at http://perma.cc/D2AB-VXCD.

${ }^{79}$ See Ricks, Regulating Money Creation, supra note 24, at 91.

${ }^{80}$ See id. at 79-80. Think of the difference here between a deposit account with check-writing privileges, and a savings account without such privileges.

${ }^{81}$ See id. at 80.

${ }^{82}$ See id. at 127.

${ }^{83}$ See supra note 76 and accompanying text.

${ }^{84}$ See Milton Friedman \& ANNA JaCOBSON SCHWARTZ, Nat'L BureaU OF ECON. ReSEARCH, A MONETARY History OF THE United STATES 1867-1960, at 299-419 (1963) (explaining that the Great Depression was caused in large part by an enormous monetary contraction); see also Ben S. Bernanke, Member, Bd. of Governors of the Fed. Reserve Sys., On Milton Friedman's Ninetieth Birthday (Nov. 8, 2002), available at http://www.
} 
contraction by pumping money into the system - this is what, for example, the Federal Reserve's Quantitative Easing has largely aimed to accomplish. ${ }^{85}$ This response, however, while necessary, can lead to other distortions in the real economy. ${ }^{86}$ While this is not the sort of

federalreserve.gov/boarddocs/speeches/2002/20021108/default.htm, archived at http://perma.cc/T9Z9-YXF7 (stating with respect to the Federal Reserve's failure to counteract monetary contraction during the 1930s, "I would like to say to Milton and Anna: Regarding the Great Depression. You're right, we did it. We're very sorry. But thanks to you, we won't do it again."). For a dissenting view on the role of monetary policy in the Great Depression, see generally Peter Temin, Did MONETARY Forces CAuSE the Great DEPRESSION? (1976) (arguing that the causal effect of a fall in aggregate demand, rather than monetary contraction, has more evidentiary support).

Paul Krugman provides a superb intuitive account of how monetary forces can affect the level of economic activity in a short essay recounting problems in a babysitting cooperative for parents who worked on Capitol Hill in the 1970s. See generally Paul Krugman, Baby-Sitting the Economy, Slate (Aug. 14, 1998, 3:30 AM), http://www.slate.com/articles/business/ the dismal_science/1998/08/babysitting the_economy single.html, archived at http://perma.cc/7AX-Y2W5. Krugman explains that the co-op issued "scrip," "pieces of paper equivalent to one hour of baby-sitting time," to ensure each couple gave as much as they received in babysitting services over the long-run. $I d$. He then relates that:

[F]or complicated reasons involving the collection and use of dues (paid in scrip), the number of coupons in circulation became quite low. As a result, most couples were anxious to add to their reserves by baby-sitting, reluctant to run them down by going out. But one couple's decision to go out was another's chance to baby-sit; so it became difficult to earn coupons. Knowing this, couples became even more reluctant to use their reserves except on special occasions, reducing baby-sitting opportunities still further.

In short, the co-op had fallen into a recession.

Id. Of course, in correcting the undersupply of scrip, the co-op eventually faced a problem of inflation. Id.

${ }^{85}$ Quantitative Easing involves the Federal Reserve buying non-traditional assets, replacing non-money assets with money for private agents. See generally Lowell R. Ricketts, Quantitative Easing Explained, ECON. INFO. NEWSL. (Fed. Reserve Bank of St. Louis), Apr. 2011, available at http://research.stlouisfed.org/pageone-economics/uploads/newsletter/2011/ 201104.pdf, archived at http://perma.cc/S7D3-J7U6.

${ }^{86}$ The Federal Reserve's actions in pumping money into the economy equate to driving (and keeping) nominal interest rates low-indeed, this is often seen as the primary policy objective, with asset purchases serving as the chosen mechanism. See id. at 1. One problem with this is that "low nominal interest 
intervention that would necessarily be made under extremely tight deadlines in response to a market on the edge of, or actually in, a state of panic - the sort of crisis response that is more the focus of this Article - the potential unintended and undesirable consequences of this policy lever should inspire regulators to take steps to ensure it is not necessary.

\section{Consequential Losses}

Understanding the money-like role of financial institutions' short-term debt claims permits us to identify another, potentially significant loss-amplification mechanism. Losses on, or delays in, redemption for assets held for transactional purposes can create consequential losses for creditors. ${ }^{87}$ Not being able to meet the types of near-term obligations for which we hold transaction reserves may lead to "opportunity costs, operational disruption, reputational damage, or even default" outstrip, the "haircut" the depositor may take if a bank cannot meet its obligations. As Walter Bagehot observed in his great $19^{\text {th }}$-century study of banking and financial markets, Lombard Street:

[U]ltimate payment is not what the creditors of a bank want; they want present, not postponed, payment: they want to be repaid according to agreement: the contract was that they should be paid on demand, and if they are not paid on demand they may be ruined. ${ }^{89}$

A more modern and colorful illustration of this dynamic is provided by the British novelist and journalist John Lanchester, describing what happened after a software update to the payment system at the Royal

rates can create incentives for certain types of investors to take added risk in an effort to "reach for yield." Jeremy C. Stein, Member, Bd. of Governors of the Fed. Reserve Sys., Yield-Oriented Investors and the Monetary Transmission Mechanism 3 (Sept. 26, 2013), available at http:/www.federalreserve.gov/ newsevents/speech/stein20130926a.pdf, archived at http://perma.cc/UXN4L6W6.

${ }^{87}$ Ricks, Regulating Money Creation, supra note 24 , at 108.

${ }^{88} I d$.

${ }^{89}$ Walter Bagehot, Lombard Street: A Description of THE Money MARKET 41 (Arno Press Inc. 1979) (1873). 
Bank of Scotland (RBS) made it impossible to make payments into or withdrawals from RBS accounts for roughly one week in June 2012:

The consequences went from the mild irritation experienced by people like me who couldn't pay their credit card bill by the due date, to, at the other end of the scale, some of the examples mentioned ungrammatically but vividly on Wikipedia: 'Completion of new home purchases were delayed, others were stranded abroad, another was threatened with the discontinuation of their life support machine in a Mexican hospital, and one man was held in prison. ${ }^{90}$

The key to preventing consequential losses from money destruction is, of course, to prevent money destruction from occurring in the first place. The most obvious way to do this is to insure money-like claims - as we do with deposit insurance, or as the FDIC and Treasury Department did with a vast array of uninsured deposit-like claims during the crisis. ${ }^{91}$

\section{Contagion}

There are several ways in which panic or instability at one financial institution may spill over to harm other financial institutions, exacerbating the three loss-amplifying dynamics outlined above. ${ }^{92}$

\footnotetext{
${ }^{90}$ John Lanchester, Are We Having Fun Yet?, LondON REV. OF BoOKS, July 4 , 2013 , at 3,6 .

${ }^{91}$ See, e.g., Luigi L. De Ghengi et al., Davis Polk \& Wardwell LLP, The FDIC's Temporary Liquidity Guarantee Program, in FINANCIAL CRISIS MANUAL: A GUIDE to THE LAWS, REgUlations AND CONTRACts OF tHE FINANCIAL CRISIS 116, 116 (2009).

${ }^{92}$ Hal Scott categorizes as "contagion" only what I call below "contagion by simile"; the other two factors categorized here as "contagion" he calls "correlation" and "connectedness." Hal S. Scott, How to Improve Five Important Areas of Financial Regulation, in RULES FOR GROWTH: PROMOTING InNOvation AND GROWTH THROUGH LEgal REFORM 113, 114 (2011), available at http://www.kauffman.org/ /media/kauffman_org/ research\%20reports\%20and\%20covers/2011/02/rulesforgrowth.pdf, archived at http://perma.cc/8JNJ-UGU7. The more common usage, however, seems to be to refer to any of the three effects as a potential type of contagion. See, e.g.,
} 
Fire sales. A financial institution facing a run-for example, a refusal by a large number of its short-term lenders to roll their debt over-may be forced to meet its obligations by selling assets. ${ }^{93}$ But there may not be ready buyers immediately available to purchase the assets for their full value. In order to offload its assets, the institution may have to engage in "fire sales" - sales of its assets for less than their "true" value. ${ }^{94}$ Not only does this harm the seller, but it may have a damaging effect on other institutions holding similar assets. ${ }^{95}$ Kashyap and his coauthors describe the problem as follows:

When bank $\mathrm{A}$ adjusts by liquidating assets - e.g., it may sell off some of its mortgage-backed securitiesit imposes a cost on another bank B who holds the same assets: The mark-to-market price of B's assets will be pushed down, putting pressure on B's capital position and in turn forcing it to liquidate some of its positions. Thus selling by one bank begets selling by others, and so on, creating a vicious circle. ${ }^{96}$

While a fire sale in itself represents a zero-sum transaction-the buyer gains to the extent that the seller loses with respect to the specific transaction-the vicious circle weakens the institutions that channel credit from savers and investors to valuable projects in the real economy, exacerbating the other loss-amplification mechanisms.

The classic response to the problem of fire sales is for the government to act as "lender of last resort." The government lends (against good collateral) so that the firm can repay its private creditors without having to liquidate its holdings in a depressed market. ${ }^{98}$ The Federal Reserve has long had a "discount window" to serve this function for commercial banks; during the crisis, it extended its lending

Fabio Caccioli et al., Stability Analysis of Financial Contagion Due to Overlapping Portfolios, 46 J. BANKING \& FIN. 233, 233 (2014).

93 See Kashyap et al., supra note 74 , at 440-42.

${ }^{94}$ Scott, supra note 92, at 116-17. "True" value here means the price the asset would fetch under normal market conditions, without time pressures or serious information asymmetries.

${ }^{95}$ See id.

${ }^{96}$ Kashyap et al., supra note 74 , at 441.

${ }^{97}$ See Colleen Baker, The Federal Reserve's Use of International Swap Lines, 55 ARIZ. L. REV. 603, 616 (2013).

${ }^{98}$ See id. 
to shadow banks through programs based on Section 13(3) of the Federal Reserve Act, which permits the Fed to lend to non-banks in "unusual and exigent circumstances.","99

Cascades. ${ }^{100}$ The failure of a large financial institution could weaken its counterparties directly as the failed firm defaults on its debts. This is often referred to as a "domino" effect, as the failure of one institution leads, we may fear, to the failure of another, which leads to another's fall, and so on. ${ }^{101}$ Some question this "domino" theory of contagion, observing that it was a common shock, not a series of dominos falling, that created problems in the recent crisis. ${ }^{102}$ While the "common shock" theory clearly has force, it also seems highly plausible that domino-type contagion was not a larger issue precisely because the government consistently stepped in to keep institutions from failing. The one time the government let a systemically important institution fail - Lehman Brothers - it led to Reserve Primary, a \$64 billion money market mutual fund, "breaking the buck" due to direct counterparty losses, forcing its failure and leading to a run on the entire money market fund industry - a potential catastrophe which, absent dramatic government intervention, could have led to economic damage orders of magnitude greater than what we saw. ${ }^{103}$

The most obvious interventions in 2008 aimed squarely at forestalling this type of domino-style contagion were the bailouts of

\footnotetext{
${ }^{99}$ See, e.g., Randall D. Guynn et al., Davis Polk \& Wardwell LLP, Federal Reserve Emergency Intervention Authority: Old Tools Used in New Ways, in Financial CRisis Manual: a Guide to the Laws, Regulations and CONTRACTS OF THE FINANCIAL CRISIS 18, 20-21 (2009).

${ }^{100}$ The term "cascades" is borrowed from ROBERT E. LITAN \& JONATHAN RAUCH, AMERICAN FINANCE FOR THE 21ST CENTURY 98-112 (1997), reprinted in RichaRd SCOTT CARNELL ET AL., THE LAW OF BANKING AND FINANCIAL INSTITUTIONS 732-36 (4th ed. 2009).

${ }^{101}$ See id. at 733.

102 See, e.g., Peter J. Wallison, Op. Ed., Dodd-Frank and the Myth of 'Interconnectedness', WALL ST. J., Feb. 10, 2012, at A15.

${ }^{103}$ For an excellent account of Reserve Primary's implosion following Lehman's bankruptcy, see generally James B. Stewart, Eight Days: The Battle to Save the American Financial System, NEW YORKER, Sept. 21, 2009, at 58. Reserve Primary, as a money market fund, issued "shares" that were worth $\$ 1$ each. Id. at 69. The "shares" were seen as a close substitute for bank deposits, however, and "breaking the buck," so that the value of each share falls below $\$ 1$, is analogous to bank depositors receiving less than $\$ 1$ for each dollar they deposited with the bank. Id.
} 
Fannie Mae, Freddie Mac, and AIG. ${ }^{104}$ The number of counterparties with direct exposure to each of these firms was staggering and included most major Wall Street firms. ${ }^{105}$

Contagion by Simile. After Reserve Primary broke the buck, a general run began on the money market fund industry, illustrating another potential type of contagion: one based on asymmetric information, where short-term creditors of the sister institutions of a failed fund or firm, with no risk tolerance for even tiny haircuts or delays in getting their money back, withdraw their money preemptively, due to a concern that the sister institution may be like the failed institution. ${ }^{106}$ This can occur even if the firm is otherwise sound-either because the firm is unable to credibly communicate its soundness to creditors (asymmetric information), or because creditors fear that other creditors may run. ${ }^{107}$ The run on money market funds during the days after Reserve Primary broke the buck provides a classic example of this type of contagion. For example, a $\$ 12$ billion money market fund run by Putnam was liquidated despite being solvent and having no exposure to either Lehman Brothers or Reserve Primary. ${ }^{108}$ This type of contagion also motivated Goldman Sachs CEO Lloyd Blankfein's concern for Morgan Stanley's health during the same

\footnotetext{
${ }^{104}$ For the terms of the government's capital injection in Fannie Mae and Freddie Mac, see generally Press Release, U.S. Treasury Dept. Office of Pub. Affairs, Fact Sheet: Treasury Senior Preferred Stock Purchase Agreement (Sept. 7, 2008), available at http://www.treasury.gov/press-center/pressreleases/Documents/pspa_factsheet_090708\%20hp1 128.pdf, archived at http://perma.cc/F9QV-5CYK. For the terms of the government's capital injections into AIG, see Guynn et al., supra note 99, at 28-32.

${ }^{105}$ See, e.g., PAULSON, supra note 69, at 4 ("[T] he collapse of Fannie and Freddie would be catastrophic. Seemingly everyone in the world-little banks, big banks, foreign central banks, money market funds-owned their paper or was a counterparty."); see also id. at 218 ("[A]n AIG bankruptcy would be devastating, leading to the failure of many other institutions.").

${ }^{106}$ See, e.g., GeITHNER, supra note 70, at 69 ("The overconfidence that fuels bubbles can become panic when bubbles pop, as investors who thought certain types of investments were perfectly safe suddenly decide that nothing that even resembles those investments is safe. Markets stop discriminating among loans, among banks, among countries.").

${ }^{107}$ Again, the possibility of a run as a self-fulfilling prophecy was modeled by Diamond \& Dybvig, supra note 33.

${ }^{108}$ See Stewart, supra note 103, at 73.
} 
period - during a call to Morgan Stanley CEO John Mack, he told him, "You have to hang on ..., because I'm thirty seconds behind you." "109

Perhaps the most important intervention to stop this type of contagion during the crisis was the move by Paulson and his team to provide a blanket guarantee to the entire money market industry. ${ }^{110}$

\section{Other Tools}

As emphasized above, the interventions outlined here are illustrative, not exhaustive. Other (non-exhaustive) responses might include asset purchases, facilitating or backstopping sales, and, notably, winding down an institution so as to minimize follow-on contagion and losses, as with the OLA under Title II of Dodd-Frank. To illustrate further the complexity of the sorts of decisions regulators face, it is also possible to conceive of a situation in which markets are just strong enough to bear the failure of a key institution, and this failure is precisely what is needed to motivate other institutional decision makers to strengthen their capital positions. Indeed, as Tim Geithner, no enemy of muscular intervention to stop a crisis, observes, "[a] central bank overreaction can even backfire right away, feeding instead of easing concern. Markets sometimes conclude a situation must be dire if policymakers act like it's dire."

\section{Importance of Experience}

Doing more good than harm in perceiving these dynamics and deciding whether and how to intervene demands an expertise born of experience (what Kahneman and Klein called "skilled intuition""112).

\footnotetext{
${ }^{109}$ ANDREW ROSS SORKIN, TOO BIG TO FAIL 448 (2009).

110 See Press Release, U.S. Dep't of the Treasury, Treasury Announces Temporary Guarantee Program for Money Market Funds (Sept. 29, 2008), available at http:/www.treasury.gov/press-center/press-releases/Pages/ hp1 161.aspx, archived at http://perma.cc/5PXM-XNA4.

${ }^{111}$ GEITHNER, supra note 70, at 120 (arguing further that "[o]ften it's better to stand back, as we had done in September 2006, when bad bets on natural gas futures sank a giant hedge fund called Amaranth Advisors. That looked like a one-off, an idiosyncratic casualty of bad risk management, unlikely to light the rest of the financial system on fire. And it was.").

${ }^{112}$ See generally Kahneman \& Klein, supra note 56. "Intuition," in this sense, means the direct apprehension of the truth without any conscious reasoning; because it is rooted in experience, there is nothing magic in it. For an influential formulation of this, see Herbert A. Simon, What Is an
} 
The relevance of crisis-fighting experience to financial regulators may seem intuitively obvious to the reader. But why, precisely, is experience important? Why wouldn't it do as well to develop comprehensive crisis-fighting guidelines and ensure that new regulators have read them? The answer, of course, is that applying valid guidelines in complex situations is not always (or usually) straightforward.

Returning to Kahneman and Klein's example of fireground commanders: ${ }^{113}$ as commanders gain experience and build their repertoire, they may not-indeed, often will not-be able to articulate precisely why they chose one course of action rather than another. ${ }^{114}$ Even if they can provide a contextualized reason for a particular decision, it may be a fool's errand to try to generalize this into an articulable rule that can reliably keep the studious novice out of trouble.

The likely futility of such an effort is captured well by a study of Canada's Emergency Response Teams ("ERTs") - the equivalent of police SWAT teams in the United States. ${ }^{115}$ The procedures for ERT missions were extensively documented and were supposed to be followed rigorously. ${ }^{116}$ The study authors slowly discovered, however, how partial a picture of the teams' work this proceduralism provided. For example,

[The teams'] training and procedure dictate that team members enter a building in formation and clear every room, starting with the ground floor and working up. However, if the operation takes place at 3:00 a.m., the chances are high that the suspect will be sleeping in the master bedroom. One ERT commander put it this

\footnotetext{
"Explanation" of Behavior?, 3 PSYCHOL. SCI. 150, 155 (1992) ("The situation has provided a cue; this cue has given the expert access to information stored in memory, and the information provides the answer. Intuition is nothing more and nothing less than recognition.") (emphasis added).

${ }^{113}$ See supra notes 56-57 and accompanying text.

${ }^{114}$ See Kahneman and Klein, supra note 56, at 516

115 KLEIN, supra note 47, at 40-41 (citing Danyele Harris-Thompson \& Sterling L. Wiggins, When SOP Is Not Enough, L. OFFICER MAG., May 2007, available at http://www.lawofficer.com/article/magazine-feature/when-sopnot-enough, archived at http://perma.cc/7NAM-ZQNA).

${ }^{116} I d$. at 40 ("The senior ERT leaders explained that they had worked out clear procedures for just about everything they did-how they approached a house or building, how they entered it, how they systematically cleared it. Everything was proceduralized, everyone knew the procedures, and everyone depended on everyone else to follow the procedures.").
} 
way: "If we clear all the rooms, by the time we get to the second floor and the bedroom, we've been in the house for two minutes ... the target is awake. Now we're putting ourselves in harm's way and compromising the mission. Therefore, we'll go directly to the master bedroom after breaching instead of procedurally clearing every room first."117

Surely, one might think, properly fleshed out procedures would take account of such a situation. The ERT manual could direct team members to go straight to the bedroom if the raid comes at night-but then "what if there is a light coming from the kitchen? Or what if they hear a door closing to a downstairs bathroom as they are getting ready to rush up the stairs?"118 One can, of course, spin out infinite variations on this theme. Writing a complete set of procedures in situations such as this evokes the difficulty in various contexts of writing a complete contract. ${ }^{119}$

In the end, one must rely on experts' "perceptual discriminations" and ability to "interpret, modify, and replace the standard procedures when they don't work." 120 These skills can be honed through actor's being forced to apply the guidelines-and thus to see how well they work or do not work-in a large number of different contexts; in other words, through experience. ${ }^{121}$

To provide an example in the context of financial crises, one of the most famous rules for preventing needless economic destruction resulting from a market panic is "[Walter] Bagehot's famous dictum" that in a financial crisis "central banks should lend early and freely (ie [sic] without limit), to solvent firms, against good collateral, and at "high rates." $" 122$ This is equivalent to the "lender of last resort" function

${ }^{117} \mathrm{Id}$.

${ }^{118}$ Id. at $40-41$.

119 The infeasibility of a complete contract justifies courts' implying contractual terms ex post; the analogue here is the expert's ability (automatically) to imply the correct move and act on it in situations not anticipated by the explicit standard operating procedures. See Jody S. Kraus \& Robert E. Scott, Contract Design and the Structure of Contractual Intent, 84 N.Y.U.L. REV. 1023, 1071 (2009).

${ }^{120}$ KLEIN, supra note 52, at 41.

${ }^{121}$ See id.

${ }^{122}$ Paul Tucker, Deputy Governor, Fin. Stability, Bank of Eng., The repertoire of official sector interventions in the financial system-last resort lending, market-making, and capital 3, (May 28, 2009), available at 
described above as a response to the problem of fire sales. ${ }^{123}$ As Gary Gorton points out, however, this hardly provides a bright-line rule for conduct:

First, when is there a 'crisis'? And furthermore, in a crisis, what is a 'solvent' firm, what is 'good' collateral, what is a 'high rate'? These are judgment calls that the central bank must make, and make quickly. It is hard to see how the answers to these questions could be prespecified as rules. And if they could, these rules would likely not be followed in the next crisis. ${ }^{124}$

In many ways, of course, this should call to mind (for the lawyer, at least) the classic distinction between rules and standards. ${ }^{125}$ While financial regulation must incorporate both rules (such as minimum capital ratios) ) $^{126}$ and standards (such as the designation of "systemically important" non-banks under the Dodd-Frank Act), ${ }^{127}$ in a crisis, with its unpredictable and constantly changing dynamics, we must increase our reliance on standards. Perhaps the most important standard, which should guide all regulator action in a crisis, yet is infinitely complex in application, is summed up best by former Federal Reserve Board of Governors member Frederic Mishkin: "you want to be tough, as long as you don't blow up the system."

http://www.bis.org/review/r090608c.pdf?frames=0, archived at http://perma. cc/Y6NU-AQPD; see also BAGEHOT, supra note 89, at 187-88.

${ }^{123}$ See supra text accompanying notes $97-99$.

${ }^{124}$ GORTON, supra note 38, at 196.

${ }^{125}$ See generally Antonin Scalia, The Rule of Law as a Law of Rules, $56 \mathrm{U}$. CHI. L. REV. 1175 (1989).

${ }^{126}$ E.g., Dodd-Frank Consumer Protection and Wall Street Reform Act $\S 115$, 12 U.S.C. $\S 5325$ (2012).

${ }^{127}$ See Dodd-Frank Consumer Protection and Wall Street Reform Act $\S 113$, 12 U.S.C. $\S 5323$ (2012).

${ }^{128}$ David Wessel, Lessons of the Rescue: A Drama in Five Acts, WALl ST. J., Sept. 9, 2013, at A1; see also GEITHNER, supra note 70, at 517 (asserting much the same point as Mishkin, but from the opposite direction stating, "Ideally, you want to provide just enough liquidity and other support for the system to prevent it from falling apart, but not so much that you sustain unsalvageable firms or unsustainable asset prices."). 


\section{Effective Intervention in a Complex Environment}

There are a number of factors that prevent the sorts of interventions discussed in Part III.B, supra, from being straightforward or easy to apply. Above all, there is the tension inherent in Mishkin's dictum ("to be tough" without "blow[ing] up the system"). ${ }^{129}$ Keeping the system from blowing up-namely by forestalling the loss propagation mechanisms described above-often involves protecting market actors from losses that they would otherwise suffer in the absence of government intervention. If market actors believe they will be protected from losses, they are less likely to take pains to avoid losses-particularly when the risk of loss goes hand-in-hand with the possibility of higher profits if things go well. ${ }^{130}$

In other words, saving the system can exacerbate moral hazard, potentially increasing the risk of future (larger) losses and instability in the system. ${ }^{131}$ Over the long term, there is also tension between promoting growth and promoting stability-for example, in the capital levels imposed on institutions. ${ }^{132}$ Given the scope of this Article, we will limit our focus here to the regulator's role once crisislike dynamics are in play, when the overriding but not sole goal must be to avoid "blow[ing] up the system"-i.e., panic and a system-wide

\footnotetext{
${ }^{129}$ Wessel, supra note 128.

130 This trade-off between risk and reward is, of course, a cornerstone of modern finance theory. To grasp the principle intuitively, consider that the yield on a "junk" bond will invariably be much higher than the yield on a U.S. Treasury bond, but the risk of default is also (invariably) much higher. See SeC. EXCh. COMm'N OfFice Of Investor EduC. \& AdVOCACY, SEC Pub. No. 150, WhAT ARE High-YIELD CORPORATE BondS? 1 (June 1, 2013), available at $\mathrm{http} / / / \mathrm{www} . \mathrm{sec}$. gov/investor/alerts/ib_high-yield.pdf, archived at http://perma.cc/3KQK-H7XD.

${ }^{131}$ It is worth noting that depositors and other money claimants (e.g., repo lenders) are typically very inefficient monitors and market disciplinarians until things reach a tipping point, at which point their method of discipline-i.e., running - creates the potentially catastrophic negative externalities that we so desperately wish to avoid. See, e.g., David Min, Understanding the Failures of Market Discipline, 92 WASH. U. L. REV. (forthcoming 2014) (manuscript at 3), available at http://papers.ssrn.com/sol3/papers.cfm?abstract_id=2403988\#\# (challenging the relevance of market discipline for financial firms).

${ }^{132}$ See, e.g., John Crawford, The Battle over Bank Capital: Determinants of An Optimal Regulatory Approach, 66 HASTINGS L.J. (forthcoming 2015), available at http://papers.ssrn.com/sol3/papers.cfm?abstract_id=2404994.
} 
withdrawal of short-term funding. ${ }^{133}$ Even as this goal dominates regulators' concerns, it must still be balanced with the subsidiary goals of managing political risk (e.g., avoiding a backlash against bailouts that ties regulators' hands and makes a system-wide blow-up likelier) and (relatedly) not permitting moral hazard to metastasize going forward. Mishkin's dictum is easy to state, but extremely difficult to apply well in practice.

A further challenge to effective intervention is that it is not always perfectly clear when the dynamics will reach, or have already reached, crisis level. ${ }^{134}$ Many did not guess that housing price declines would reverberate as they did. ${ }^{135}$ Resolving a problem bank too early could be needlessly disruptive and possibly spark market jitters that harm otherwise sound banks (contagion by simile), ${ }^{136}$ waiting too long (e.g., by exercising "regulatory forbearance") 137 could allow firms to deepen their balance sheet holes - and the cost of the ultimate reckoning - by "gambling for resurrection." "138

Even when there is consensus that crisis-like dynamics are at play, it is not always clear how much the crisis is driven by fundamental insolvency as opposed to illiquidity. ${ }^{139}$ Of course, one type of crisis might easily morph into the other: for example, a solvent firm that has to engage in fire sales in order to manage a liquidity squeeze

\footnotetext{
${ }^{133}$ Wessel, supra note 128.

${ }^{134}$ See supra note 70 and accompanying text.

135 The release of transcripts from the Fed's meetings in 2008 provide a rare glimpse into the degree regulators were trying to make sense-with varying levels of success — of the (first slowly, then rapidly) developing crisis. See, e.g., Jon Hilsenrath, New View Into Fed's Response To Crisis, WALl ST. J., Feb. 21 , 2014, at Al (discussing how Federal Reserve officials "spent much of the spring and summer [of 2008] hamstrung by uncertainty, disagreement and an unexpected inflation jump," and how two days after the collapse of Lehman Brothers, Federal Reserve Chairman Bernanke said, concerning the Fed's interest rate policy, "I think that our policy is looking actually pretty good.").

${ }^{136}$ See supra text accompanying notes 106-10.

${ }^{137}$ See, e.g., Cheryl D. Block, A Continuum Approach to Systemic Risk and Too-Big-to-Fail, 6 BROOK. J. CORP. FIN. \& COM. L. 289, 301 (2012).

138 ANAT AdMATI \& Martin Hellwig, The Bankers' New Clothes: WHAT'S WRONG WITH BANKING AND WHAT TO DO ABOUT IT 43 (2013) (explaining that when a company is insolvent its shareholders may wish to see the company make bets that have a negative expected net present value, as long as the upside in the event the bets pay off will put the shareholders back in the black).

${ }^{139}$ See id. at 32 .
} 
may become insolvent (as it gets less for its assets than they were "really" worth). ${ }^{40}$ More generally, if the government does not intervene effectively in a liquidity crisis and the financial system collapses as a result, then depression would ensue, businesses would collapse, people would lose their jobs, and a raft of consumer and business credit defaults would lead to an insolvency crisis. One of the fiercest intra-administration fights at the beginning of President Obama's first term was over the strategy pushed by Tim Geithner, in his new role as Treasury Secretary, to subject large financial institutions to "stress test[s]." 141 The tests would be used to gauge whether institutions had sufficient capital buffers to withstand further adverse shocks. ${ }^{142}$ Those firms deemed to have insufficient capital would have to make up their capital shortfall either by raising funds from private investors or by accepting an investment (with generally unfavorable terms for the bank) from the government. ${ }^{143}$ Geithner, who had a hunch banks were not quite as bad off as many believed, thought the tests might provide a chance for markets to regain confidence and inject capital into the banks again. ${ }^{144}$ Geithner's erstwhile mentor and President Obama's new director of the National Economic Council, Larry Summers, believed that the banks were in much worse condition, that more drastic action (such as nationalization) was necessary, and that stress tests would only extend the pain. ${ }^{145}$ Geithner's plan won out and he was ultimately vindicated as every single financial institution either passed the test or was able to raise the required funds in private markets, ${ }^{146}$ but the fact that some of the economy's and markets' most sophisticated observers feared more intractable insolvency problems points to the difficulty of interpreting data in real time, in the "fog of war."

A possible but ultimately incomplete response to the concern about the opacity with which regulators must struggle in responding to

${ }^{140}$ See id.

${ }^{141}$ GeITHNER, supra note 70 , at $286-89$.

${ }^{142} I d$. at 286.

${ }^{143} I d$. at 287.

${ }^{144} I d$. at $286-87$.

${ }^{145} \mathrm{Id}$. at 288 ("Larry worried that the stress test would be viewed as a whitewash, a mechanism to prop up zombie banks."); id. at 321. ("His recurrent theme was that our plan was too reminiscent of Japan, which had kept its zombie banks alive and suffered the consequences of its timidity, and not enough like Sweden, which had nationalized banks and enjoyed a buoyant recovery.").

${ }^{146}$ See, e.g., Brandow et al., supra note 77 , at 68. 
a crisis in real time is that more disclosure and better information might be able to dissipate the fog. While the lack of good data was a glaring problem in the recent crisis, and continues to be a major concern, ${ }^{147}$ there are reasons to be skeptical that more data and more informationas important as they may be - can solve all our problems. Klein argues persuasively that sufficient information was available to predict a number of traumatic crises prior to their occurrence, if policy-makers had been appropriately focused on it, or if the system had had better filters. ${ }^{148}$ He highlights in this vein intelligence that could or should have provided U.S. policymakers with advance notice of the 9/11 attacks and the attack on Pearl Harbor, as well as early public disclosures that should have alerted securities regulators to the accounting shenanigans at Enron. ${ }^{149}$ At a certain point, decision makers' ability to make sense of data becomes much more important than the addition of any new data: "There is no point," Klein observes, "at which enough data will magically coalesce and produce meaning. People have to make sense of the details." 150 A useful metaphor for "mak[ing] sense" of information is "connecting the dots." " Models show us how to connect the dots, but experience is essential for recognizing in complex situations "what counts as a dot,"152 and in helping us recognize which dots are needed to complete a given picture. ${ }^{153}$

A third reason it may be difficult to apply guidelines in a straightforward manner is the degree to which crisis response invites

147 See, e.g., Andrew Haldane, Towards a common financial language 1 (Mar. 14, 2012), available at http://www.bankofengland.co.uk/publications/ Documents/speeches/2012/speech552.pdf, archived at http://perma.cc/YL259TF6 (comparing the lack of a common language in the financial system, and thus the difficulty of integrating and communicating key data and information, to the biblical punishment of those building the Tower of Babel).

${ }^{148}$ KLEIN, supra note 52, at 136-43.

${ }^{149}$ Id: see generally Malcolm Gladwell, Open Secrets: Enron, Intelligence, and the Perils of Too Much Information, NEW YORKER, Jan. 8, 2007, at 44 (making a similar argument with respect to Enron).

${ }^{150}$ KLEIN, supra note 52, at 135.

${ }^{151} I d$. at 127.

${ }^{152} I d$. (emphasis added).

${ }^{153} \mathrm{Id}$. at 184 ("[W]hen we make sense of events we usually are seeing only some of the dots that complete the picture, trying to remember others, discarding 'wannabe' dots, and adjusting dots that have gotten distorted."). 
withering political scrutiny. ${ }^{154}$ This is in part because of what Gary Gorton calls the "paradox of financial crises": in a systemic crisis, "what feels just and fair is the opposite of what's required for a just and fair outcome." 155 Even if one accepts this paradox as true, however, it is important to acknowledge that crisis management necessarily involves some degree of "picking" winners and losers. ${ }^{156}$ This makes crisis intervention especially politically fraught. ${ }^{157}$ The Lehman scenario laid out in the next section provides a vivid example of how deeply crisis management affects and is affected by the political backdrop.

A fourth challenge to effective crisis response is the possibility of strategic behavior by key actors in the political and financial system. This, again, played a central role in the decisions leading up to Lehman's failure, as the next Part will make clear.

Finally, it is worth emphasizing that effective crisis management is as much about anticipating and being prepared to counter the negative fallout of key actions or omissions as it is about

154 A persistent theme of the memoirs borne of the financial crisis is the toxicity of the politics surrounding crisis response. For example, after describing his work on the Treasury Department's response to Mexico's "peso crisis" of 1994, Tim Geithner writes that by late 1995,

Mexico had fallen out of the news, and neither the success of the rescue nor the fact that we recovered our investments plus a profit got much attention-certainly not enough to offset the political hit that Clinton and Rubin took around the initial decision.

Mexico was a bracing lesson in the terrible politics of crisis response. I had never worked on something so controversial before, and it was searing to watch the abuse showered on Rubin and Greenspan-then near the peak of their public credibility—for taking a risk that seemed so compelling to me.

GEITHNER, supra note 70, at 51.

${ }_{155}^{155}$ GORTON, supra note 38, at 166 (quoting Timothy Geithner).

${ }^{156}$ For example, while one can tell compelling (and true) stories based on regulators' and politicians' understanding of the urgency of the moment as to why (to pick two examples) Bear Stearns was "saved" but Lehman was left to bankruptcy, or why the uninsured creditors of Washington Mutual did not receive full recoveries but the uninsured creditors of Wachovia did, this is unlikely to assuage the "losers" in these cases. For an analysis of the Crisis with a focus on the political aspects of regulators' response to it, see generally, e.g., Adam J. Levitin, The Politics of Financial Regulation and the Regulation of Financial Politics, 127 HARV. L. REV. 1991 (2014) (book review).

${ }^{157}$ See GoRTON, supra note 38, at 166. 
making the decision that ex post appears right in every case. Once again, the Lehman saga provides a perfect illustration of this.

\section{E. Lehman Brothers: A Case Study in the Challenges of Effective Intervention}

When Lehman Brothers, the venerable investment bank, filed for bankruptcy on September 15, 2008, the fallout was terrifying. ${ }^{158} \mathrm{In}$ terms of the mechanisms outlined in Part III.B, Lehman's failure led to the destruction of money claims and consequential losses, ${ }^{159}$ as well as contagion by cascade and contagion by simile. ${ }^{160}$ As James Stewart recounts in his 2009 New Yorker article about the days surrounding the beginning the crisis:

The [anonymous] Treasury official described the situation: "Lehman Brothers begat the Reserve [Primary] collapse, which begat the money-market run, so the money-market funds wouldn't buy commercial paper. The commercial-paper market was on the brink of destruction. At this point, the banking system stops functioning. You're pulling four trillion out of the private sector"-money-market funds"and giving it to the government in the form of T-bills. That was commercial paper funding GE, Citigroup, FedEx, all the commercial-paper issuers. This was

158 See, e.g., Susanne Craig et al., AIG, Lehman Shock Hits World Markets, WALl ST. J., Sept. 16, 2008, at A1.

159 The most salient example is, of course, Reserve Primary's failure: it held Lehman securities it believed to be (almost as) liquid and price-protected as money; when these claims became non-money-like (i.e., illiquid and highly volatile claims on the Lehman estate), it led to the destruction of the immense and venerable money market fund. See generally Stewart, supra note 103.

160 Reserve Primary's insolvency was the result of direct losses on its investment in Lehman's securities; the failure of Lehman in turn exacerbated a run on Morgan Stanley, not because of Morgan Stanley's exposure to Lehman, but because it was seen as "like" Lehman in terms of its vulnerabilities. On the liquidity problems of Morgan Stanley during the days leading up to and following Lehman's failure, see Darrell Duffie, Replumbing Our Financial System: Uneven Progress, INT'L J. CENTRAL BANKING, Jan. 2013, at 251, 276 fig. 13 (showing the "[s]ources of [1] oss to Morgan Stanley's [1]iquidity [p]ool, [from] September 10-22, 2008"). 
systemic risk. Suddenly, you have a global bank holiday." 161

The lead-up to Lehman's collapse has been chronicled elsewhere in great detail, ${ }^{162}$ but a very brief outline of certain key events and decisions will help frame and amplify several of the key points made in Section III.D - namely the difficulty of responding to a crisis when one has conflicting objectives; the political challenge of crisis intervention; the central role of strategic behavior; and the importance of regulators anticipating and preparing for potential bad outcomes from interventions or failures to intervene.

Lehman Brothers had been on regulators' radar throughout the summer of 2008 as a potential source of trouble, and by early September it was on the verge of failing. ${ }^{163}$ Creditors were rapidly losing confidence in Lehman and were withdrawing funding; by Friday, September 12, it was clear that without a drastic third-party intervention, Lehman would not be able to meet all its obligations on Monday and would fail. ${ }^{164}$ Regulators hoped to persuade a stronger financial firm to buy Lehman over the weekend, so that creditors would regain confidence and roll over their debt. ${ }^{165}$ The problem, however, was that Lehman was sitting on losses large enough that no firm was willing to pay a positive price for the firm. ${ }^{166}$ The Fed had solved a similar problem when Bear Stearns had been sold to J.P. Morgan six months earlier by assuming the risk of losses on roughly $\$ 30$ billion of Bear's bad assets. ${ }^{167}$ Political and public sentiment had, however, turned sharply against bailouts. ${ }^{168}$ Just days before, the government had placed Fannie Mae and Freddie Mac into receivership, and injected enough capital into the two government-sponsored entities to ensure creditors would not suffer losses. ${ }^{169}$ As James Stewart recounts in his

${ }^{161}$ Stewart, supra note 103 , at 73 .

${ }^{162}$ See, e.g., PAULSON, supra note 69, at 122-221; SORKIN, supra note 109.

${ }^{163}$ See PAULSON, supra note 69 , at 122-221.

${ }^{164}$ See id. at $186-92$.

${ }^{165} \mathrm{Id}$.

${ }^{166} I d$. at $181-82$.

${ }^{167}$ GEITHNER, supra note 70, at 156; Guynn et al., supra note 99, at 26.

${ }^{168}$ Stewart, supra note 103 , at 80.

169 PAUlson, supra note 69, at 3 ("But Fannie and Freddie were congressionally chartered companies that already relied heavily on implicit government support, and in August, along with Bernanke, I'd come to the conclusion that taking them over was the best way to avert a meltdown, keep mortgage financing available, stabilize markets, and protect the taxpayer."). 
New Yorker article, "Public criticism of Paulson and Bernanke was scathing. The bailouts had brought into rare alignment the Republican right wing, averse to any tampering with the free market, and the Democratic left, outraged by the government rescue of Wall Street's overpaid élite." ${ }^{170}$ Paulson recounts in his memoirs calls from Congressional leaders warning him against putting taxpayer money on the line; Senator Chris Dodd, for example, told him, "“[the President and CFO of Lehman Brothers, Richard] Fuld is a friend. Try to help, but don't bail Lehman out."

It was against this anti-bailout backdrop that Paulson and his team sought plausible buyers of Lehman. ${ }^{172}$ There were two heading into the weekend: Bank of America and Barclays, a British bank. ${ }^{173}$ Bank of America's CEO, Ken Lewis, insisted on getting a "Jamie deal," after the arrangement J.P. Morgan chief Jamie Dimon negotiated in March for the Bear Stearns purchase. ${ }^{174} \mathrm{He}$ wanted to leave the "bad" assets behind, with losses to be assumed by the government. ${ }^{175}$ Paulson was adamant in communicating to Lewis and to everyone else that no public money would be used to support the deal, in line with the intense political pressure being brought to bear on him. ${ }^{176}$ Despite Paulson's efforts to assure Lewis that he would try to come up with a solution for the bad assets that involved a private, rather than a public, bailout, ${ }^{177}$ Lewis moved on from Lehman and set his sights on its slightly less weak rival, Merrill Lynch. ${ }^{178}$ Thus, only Barclays was left in play to buy Lehman. Paulson and other top regulators, continuing to insist that no public money could be committed to support a deal, were

\footnotetext{
${ }^{170}$ Stewart, supra note 103 , at 60 .

${ }^{171}$ PAULSON, supra note 69, at 181.

${ }^{172}$ See id. at $122-221$.

${ }^{173} I d$. at 192.

${ }^{174}$ SORKIN, supra note 109, at 278-79 (“"We've looked into it and we can't do it-we can't do it without government assistance,' Lewis said levelly.").

${ }^{175} I d$. at 279.

${ }^{176}$ GeITHNER, supra note 70, at 178 ("All week long, Hank had stuck to a consistent message in his private calls to the market: The government will not subsidize the purchase of Lehman.").

${ }^{177}$ SORKIN, supra note 109, at 279 (reporting that after Paulson told Lewis he would try to get Lewis the protection he needed from the private sector, "Lewis paused, not at all pleased with what Paulson seemed to be suggesting. He didn't want to get involved in a quasi-public-private rescue; he wanted a 'Jamie deal.' And he knew full well that his rivals were unlikely to want to foot the bill so he could buy Lehman for a song.").

${ }^{178} I d$. at $322-23$.
} 
(quite remarkably) able to persuade and cajole the other major Wall Street chiefs to agree to fund a vehicle to hold Lehman's most toxic assets, accepting the (high) risk of loss on these assets. ${ }^{179}$ It seemed like a deal was in the offing and Lehman would be saved. ${ }^{180}$ Alas, Barclays' regulators in the United Kingdom, refused to greenlight the deal. ${ }^{181}$ With no buyer and no time, Lehman was forced to file for bankruptcy. ${ }^{182}$

${ }^{179}$ PAULSON, supra note 69, at 210 ("In the end, they had come much further than Tim and I thought they would. They had agreed to put up more than $\$ 30$ billion to save their rival, and they had figured out how to spread the risk across the industry.").

${ }^{180}$ See id.

${ }^{181} \mathrm{Id}$. at $210-11$. Paulson admits to misreading the tea leaves heading into the weekend. Specifically, he ignored a vague warning from Alastair Darling, Chancellor of the United Kingdom Exchequer, that the British were not enthusiastic about Barclays as a buyer for Lehman. Id. at 187-88 ("Afterward I commented to Jim Wilkinson that Alistair seemed to be telling me that the British didn't want their banks to catch the American disease. But because he couched this as a general concern, I didn't see his words as the red flag that in retrospect they appear to have been.").

${ }^{182}$ Paulson, Bernanke, and Geithner all insist that they had no legal authority to rescue Lehman. See Phillip Swagel, Why Lehman Wasn't Rescued, N.Y. TimES ECONOMIX (Sept. 13, 2013, 1:18 PM), http://economix.blogs.nytimes.com/ 2013/09/13/why-lehman-wasnt-rescued/?_php=true\&_type=blogs\&_r=0, archived at http://perma.cc/99QX-A6Q8. Some commentators question their insistence, believing they could in fact have saved Lehman, even after all the other chips had fallen by the afternoon of Sunday, September 14. There are two measures critics appear to assume the Federal Reserve and/or Treasury could have undertaken. First, they assume they could have injected capital into Lehman Brothers, as they ultimately did with General Motors and Chrysler, and with Citigroup and Bank of America, and a host of other financial institutions. See, e.g., RiCHARD A. POSNER, A FAILURE OF CAPITALISM 277 (2009) ("If they could lawfully bail out insolvent auto manufacturers, they could lawfully have bailed out an insolvent investment bank."). But all these capital injections were carried out under the aegis of the Troubled Asset Relief Program (TARP), which was not authorized by Congress until the enactment of the Emergency Economic Stabilization Act on October 3, 2008, eighteen days after Lehman Brothers filed for bankruptcy. See Swagel, supra. Second, they argue that the Federal Reserve could have lent to Lehman under section 13(3) of the Federal Reserve Act, which permits collateralized lending to nonbank institutions in "unusual and exigent circumstances." See supra text accompanying note 100 . This is what the Federal Reserve had used to backstop the sale of Bear Stearns to J.P. Morgan in March 2008, what underlay several broader-based liquidity facilities the Fed made available to broker-dealers 
This tragic story illustrates the tension between being tough and saving the system. According to all credible accounts, top financial regulators desperately wanted for Lehman to survive, but they wanted almost as much to avoid putting taxpayer money into it. ${ }^{183}$ Again, the pressure on top financial regulators not to bail out Lehman Brothers was extraordinary. ${ }^{184}$ In the two days after news that Lehman would file for bankruptcy became public, the Wall Street Journal and the New York Times, whose editorial boards can generally be expected to take opposite sides of any given issue, both published laudatory editorials. ${ }^{185}$

Despite all this, Paulson claims that if there had been a legal way to put government money into Lehman to save it, he would have done it rather than let it file for bankruptcy. ${ }^{186}$ So what happened?

Here the centrality of strategic behavior comes into focus. Regulators' order of preferences heading into the Lehman weekend appears to have been as follows: (1) to facilitate a sale without public money; (2) to facilitate a sale with public money (by, e.g., assuming the risk of loss on bad assets); and (3) to allow Lehman to file for

starting in March 2008, and what the Fed relied on in bailing out AIG. See Guynn et al., supra note 99, at 18 . The key distinction between Bear and Lehman is that in the latter case there was no private buyer; and the key distinction between Lehman and AIG is that AIG's problem was seen as one of liquidity rather than solvency, whereas Lehman was deemed to have a deep capital hole, and no one could quite see to the bottom of it. See PaUlson, supra note 69, at 208, 229. ("U]nlike with Bear Sterns, the Fed's hands were tied [with Lehman] because we had no buyer. . . . Unlike with Lehman, the Fed felt it could make a loan to help AIG because we were dealing with a liquidity, not a capital, problem.").

${ }^{183}$ See, e.g., GEITHNER, supra note 70 , at 178-79.

${ }^{184}$ See id. at 178 ("[A]fter [the bailouts of] Bear and Fannie and Freddie, Washington had become a cauldron of Old Testament populism and moral hazard fundamentalism.").

${ }^{185}$ Editorial, Wall Street Casualties, N.Y. TIMES, Sept. 16, 2008, at A28 ("It is oddly reassuring that the Treasury Department and Federal Reserve let Lehman Brothers fail . . . [B]arring the risk of cascading failures, regulators finally seem willing to hold Wall Street accountable for its mistakes."); Editorial, Wall Street Reckoning, WALL ST. J., Sept. 15, 2008, at A22. ("[T]he government had to draw the line somewhere .... Secretary Hank Paulson's refusal to blink won't get any second guessing from us.").

${ }^{186}$ See Stewart, supra note 103, at 63 ("Paulson now acknowledges ... that the government was more amenable to funding a rescue than it let on. 'We said, 'No public money,' . . 'We said this publicly. We repeated it when these guys came in. But to ourselves we said, 'If there's a chance to put in public money and avert a disaster, we're open to it."'”). 
bankruptcy. In order to try to achieve regulators' first preference, Paulson had to bend over backwards to signal that his third preferred outcome dominated his second preferred outcome-this is the only way that could have motivated the Wall Street chiefs to agree to absorb losses in the wake of a sale. ${ }^{187}$ In doing so, however, he drove away Bank of America. ${ }^{188}$ If Paulson had been able to credibly promise Lewis that he would be able to leave Lehman's most toxic assets behind in buying the firm-with losses to be borne hopefully by other private banks, but if not, then by the government-he likely could have avoided outcome (3), but he also would have thereby made outcome (1) impossibly difficult to achieve, as the other Wall Street banks would have been far more resistant to funding a vehicle with Lehman's worst assets if they knew the government would fill the role in extremis. ${ }^{189}$

Despite the devastating fallout from Lehman's failure, it is not clear that regulators made the wrong choices that weekend from an ex ante perspective. First, the nature of complex systems is such that even the best moves sometimes fail due to bad luck. Second, the financial environment was such that a Lehman bailout may not have ended the bleeding - the "sharks" may have next turned their attention to Merrill Lynch if Bank of America was busy trying to digest Lehman, and a similar game would have played out a week later. Indeed, given the weaknesses in financial markets, as well as the intensely anti-bailout political environment of the moment, it is not clear even from an ex post perspective that putting public money on the line would have been preferable to failure. It is possible, on the contrary, that Lehman was a necessary sacrifice in order for the public and key lawmakers to support, or at least condone, the extraordinary steps that were neededand might have eventually been needed regardless of Lehman - to stabilize the system. Tim Geithner recounts a conversation he had with Barney Frank as the destruction of Lehman's failure was becoming clear: "If nothing else, [Frank] mused, the terror of the free fall could dampen enthusiasm for government inaction, and shock the political world into taking the crisis seriously. 'Maybe this will shut up the crazies,' he said." 190

It is easy to imagine a scenario, then, in which saving Lehman would have made it much more difficult to take these steps, and the destructive dynamics playing out in the financial system would have

\footnotetext{
${ }^{187}$ See GEITHNER, supra note 70, at 178.

${ }^{188}$ SORKIN, supra note 109 , at 279.

${ }^{189}$ See id.

${ }^{190}$ GeITHNER, supra note 70, at 192.
} 
had more time to wreak their havoc before they could finally and effectively be quashed. This counterfactual is, of course, highly speculative. Returning to the most straightforward defense of regulators' decisions that weekend: the fact that in complex environments the "right" demonstrates not that expertise is irrelevant but rather the importance of having regulators who can anticipate, and therefore be prepared to respond to, the (always possible) worst-case outcome.

Regulators may not have been prepared for the terrible consequences of Lehman, but they adjusted quickly and engaged in a breathtaking range of actions to save the system in the days, weeks, and months following the bank's collapse. These included many of the interventions described in Part III.B, supra, including guaranteeing money market fund accounts, guaranteeing all bank debt, asking for and facilitating the enactment of the EESA and TARP, injecting capital into banks, and bailing out and taking over AIG. ${ }^{192}$

While wargame design will be discussed in more detail in Part IV.A, infra, it is worth pausing here to consider some of the lessons relevant to such design that may be drawn from the Lehman saga. First, the Lehman story suggests that, to the extent possible, simulations should incorporate potentially adverse political conditions into the decision-making calculus participants face. Second, close case studies of specific crisis incidents may be worth combining with (extensive) research of current market institutional arrangements in designing games. Finally, wargames should provide regulators experience in trying to recover from catastrophic decisions, as well as experience in trying to avoid them.

As I argue in Part IV, infra, while it is unlikely a Lehman-like situation would play out in precisely the same way during the next crisis, having lived through it—or simulated variations of it—can help

191 "Right" here is not used in any absolute sense but rather "means a decision the likely outcome of which has envisioned benefits for the decision maker." Robert C. Rubel, The Epistemology of War Gaming, NAVAL WAR C. REV., Spring 2006, at 108, 127 n.5. Rubel continues, "Clearly, even 'right' decisions could result in failure due to bad luck (statistically speaking) or the intervention of imponderable factors." Id.; see also GEITHNER, supra note 70, at 46 (citing former Secretary Treasury Robert Rubin's admonition that "[Y] $]$ ou can't judge a decision by how it turns out, only by whether it made sense given the information available at the time.").

192 See generally DAVIS POLK \& WARDWELL LLP, FinANCIAL CRISIS MANUAL: A GUIDE to THE LAWS, REgUlations and CONTRACTS OF THE FINANCIAL CRISIS (2009). 
prepare regulators to better anticipate potentially adverse consequences from decisions on whether to intervene in a crisis, to integrate consideration of the risk of such consequences quickly into the decision-making process, and to think through provisional steps to address possible vicious side effects arising from any particular regulatory act or omission.

\section{F. Regulator Experience and the 2008 Crisis}

Regulators clearly made mistakes in responding to the crisis, ${ }^{193}$ but I accept the view that regulators' actions post-Lehman saved us from a second Great Depression. ${ }^{194}$ It may be worth noting here that some of our top regulators did in fact have some relevant experience with crisis-like conditions prior to 2007-08. In particular, Tim Geithner, at the time head of the New York Fed, had been one of the top deputies

${ }^{193}$ If letting Lehman fail was not a mistake, then failing to recognize at an earlier date the magnitude of the crisis certainly was. See, e.g., Hilsenrath, supra note 135 ("Two days after U.S. officials decided to let Lehman Brothers collapse in September 2008, and just before the Federal Reserve unleashed a torrent of programs to bolster the financial system, central-bank officials were still struggling to grasp the magnitude of the calamity that had hit the economy.").

${ }^{194}$ See, e.g., GeITHNER, supra note 70, at 199 ("We had just suffered a financial shock worse than the one that had led to the Great Depression. Market volatility was more than a third higher than it had been after the crash of 1929; bond spreads would rise more than twice as high; the percentage of household wealth lost would be more than five times worse than in 1929."). Larry Summers, former Treasury Secretary to President Clinton and director of President Obama's National Economic Council, has observed that most economic indicators were worse in the fall of 2008 than they were in the fall of 1929 and the winter of 1930- but the aftermath has been significantly less awful than during the Depression. Larry Summers, Remarks at IMF Fourteenth Annual Research Conference in Honor of Stanley Fischer (Nov. 8, 2013), available at http://arrysummers.com/imf-fourteenth-annual-researchconference-in-honor-of-stanley-fischer/, archived at http://perma.cc/86YL2SXE ("We have all agreed, and I think our agreement is warranted, that a remarkable job was done in containing the 2007-2008 crisis. That an event that in the fall of 2008 and winter of 2009 that appeared, by most of the statisticsGDP, industrial production, employment, world trade, the stock marketworse than the fall of 1929 and the winter of 1930, ended up in a way that bears very little resemblance to the Great Depression."). He attributes this largely to the regulatory response to the financial crisis in the last months of 2008. Summers, supra. 
at the Treasury Department during the sovereign debt crises of the 1990s. ${ }^{195}$ He later observed:

Just about every debate we had during the Asian [sovereign debt] crisis would recur in the global crises a decade later: tough love versus unconditional love, Old Testament justice for arsonists versus pragmatic concern for innocents, transparency versus reassurance, austerity versus stimulus, liquidity versus solvency. In every country, we debated how long to let the fire burn before we should intervene aggressively, what the likelihood was that it would spread, and whether the people we wanted to save could be trusted to do what they promised. ${ }^{196}$

Geithner played a key role in stemming the crisis, and his experience with the crises of the 1990 s was formative ${ }^{197}$ It is likely that the crisis response would not have been as effective as it was if one of the key decision makers had not had actual experience dealing with sovereign debt crises, which involve international investors running on a country's banking system and/or refusing to roll over the government's debt. ${ }^{198}$ It would be a mistake, however to take the presence of an experienced decision maker in a crisis for granted. It was arguably a stroke of luck that the position of president of the New York Fed happened to be filled by someone with Geithner's crisis-fighting experience. Furthermore, it seems likely that the crisis response was hampered by the dearth of crisis-fighting experience among other key decision makers. ${ }^{199}$ Geithner recently remarked in an interview with

${ }^{195}$ See GeITHNER, supra note 70 , at 37-74.

${ }^{196} I d$. at $69-70$.

${ }^{197}$ Geithner reports a joke about the danger of confusing correlation for causation made by the governor of the Bank of England, Mervyn King, who observed, "Tim was present at all the crises ... But he didn't cause the crises. The crises caused him." GEITHNER, supra note 70, at 74 .

${ }^{198}$ See Hao Li, What Is a Sovereign Debt Crisis? Why Is It So Scary?, INT'L Bus. TIMES (Nov. 19, 2011, 11:19 AM), http://www.ibtimes.com/whatsovereign-debt-crisis-why-it-so-scary-372228, archived at http://perma.cc/ 9JQ5-AU33.

${ }^{199}$ For example, Geithner convincingly argues that the FDIC's handling of Washington Mutual's failure, shortly after Lehman, was severely bungled, damaging confidence almost as much as the Lehman failure. Specifically, he argues that the FDIC should have invoked the "systemic risk exception" to 
The Financial Times that during the crisis the Fed and Treasury had "really remarkably collaborative and exceptionally talented people. But I can tell you that the ... practical knowledge base in those institutions of what you do in a systemic panic was very limited . . ." "200

In a way, then, Geithner's story strengthens the case for creating ersatz experience for regulators. At the same time, his career path suggests that another possible way for regulators to attain relevant crisis-fighting experience may be through exposing them to financial crises in other countries, either as, for example, a staffer with the international finance team at the Treasury Department, or through secondment to foreign regulatory agencies. ${ }^{201}$

In addition to Geithner, Secretary Paulson was on the management team at Goldman Sachs during its near-death experience in 1994 and during the rescue of faltering hedge fund Long Term Capital Management in $1998^{202}$ - hardly preparation for the events of 2008 , but far more relevant than the experience of the previous two Secretaries, both of whom had been chief executives at industrial firms. ${ }^{203}$ And Fed chairman Bernanke, though lacking direct crisisfighting experience, complemented Paulson's market knowledge and Geithner's crisis-fighting experience with a deep understanding of depression economics. ${ }^{204}$

avoid creditor haircuts, since failing to do so in the midst of a panic would exacerbate the run on the system and worsen FDIC losses in the long run. GEITHNER, supra note 70, at 214-16.

${ }^{200}$ Transcript: Martin Wolf Interviews Tim Geithner, FIN. TIMES (June 2, 2014, 12:45 PM), http://www.ft.com/cms/s/2/3d655d68-e978-11e3-99ed00144feabdc0.html\#axzz3HkpKKw94, archived at http://perma.cc/ZU2FSU36.

${ }^{201}$ See, e.g., GERDING, supra note 30, at 499 ("Regulators from these [e.g., securities and consumer finance] agencies should be regularly seconded to the fledgling international organizations for regulatory cooperation, such as IOSCO for securities regulators. Moreover, agencies should second staff to counterparts in other countries in regular rotations. For example, regulators from Britain's Financial Services Authority could be assigned to a tour of duty with its counterpart in Japan.").

${ }^{202}$ PAULSON, supra note 69, at 33-34.

${ }^{203}$ Paulson's predecessors were Paul O'Neill, former chief executive of Alcoa, and John Snow, former chief executive of CSX.

${ }^{204}$ Bernanke was one of the leading scholars of the Great Depression prior to joining the Fed. See Meet Ben Bernanke: Depression Scholar, Superhero, NEwSWEEK (Oct. 17, 2008, 8:00 PM), http://www.newsweek.com/meet-ben- 


\section{G. The Difficulty of Getting Experience}

Assuming financial crises provide a valid environment and that experience can help regulators build expertise in responding to crises, the question arises as to how easy it is for regulators to get the relevant experience to improve their crisis-fighting skills. Here we face a problem articulated by Andrew Haldane in a widely-cited speech he delivered at the Fed's annual conference in Jackson Hole in 2012. ${ }^{205}$ Haldane argued that the complexity of the financial regulatory "playbook" was counterproductive and that a better approach would combine a simplified rulebook with more experienced regulators. ${ }^{206}$ Yet, Haldane observed:

Therein lies a dilemma. Galbraith observed that: "There can be few fields of human endeavour in which history counts for so little as in the world of finance." A full crisis cycle might last 20-30 years. A systemic crisis might only occur once or twice a century. Among risk managers, typical levels of experience are significantly less than a full crisis cycle. The same is true among bank supervisors. ${ }^{207}$

Financial crises are of the utmost public concern even if they occur relatively infrequently - but it is a challenge, given their infrequency, for regulators to develop experience in crisis-fighting and to put it to use in the next crisis. It would seem, then, that the two requirements other than validity for the development of reliable intuitive judgment by experts are lacking: the chance to practice and receive feedback.

The next section takes up the possibility-the promise and the challenges-of attempting to manufacture some relevant expertise, to provide regulators with the opportunity to practice crisis-fighting, and to provide them with feedback on the plausible consequences of their decisions and actions. We will draw from another field where experience is important to performance, and where such experience is

bernanke-depression-scholar-superhero-91865, archived at http://perma.cc/ SP5L-M99V.

${ }^{205}$ Andrew G. Haldane, Exec. Dir., Fin. Stability, Bank of Eng., The dog and the frisbee (Aug. 31, 2012), available at http://www.bis.org/review/ r120905a.pdf, archived at http://perma.cc/FG6K-VHC2.

${ }^{206} \mathrm{Id}$. at $16-17$.

${ }^{207} I d$. (citation omitted). 
(thankfully) hard to come by for long periods of time: wargames in the military

\section{Manufacturing Experience with Wargames}

Experience can contribute to regulatory expertise in crisis management, yet is hard to attain due to the relative infrequency of crises. ${ }^{208}$ Can we nonetheless try to manufacture experience so that regulators are better equipped to respond to crises and to limit damage to the real economy when crises occur? This Section considers the possibility of building regulators' crisis-fighting skills by exposing them to simulations, or wargames, of financial crises. I begin this Section with a description of what I mean by wargames, followed by a brief account of how wargames are already used to simulate financial crises. Then I outline the potential advantages of wargames - how they can work to improve regulatory skill-as well as some of the risks, challenges, and potential limitations with respect to their use.

\section{A. Wargames: Definition and Design}

As a brief prefatory note, I use "crisis simulation" interchangeably with "wargame." The term "wargame," however, evokes a broader range of purposes, particularly with respect to the military's tradition of using it as a tool to develop leaders and to improve strategic (not just tactical) thinking among its decision makers.

What is a wargame? Peter Perla, a leading authority on the subject, defines it as "a warfare model or simulation in which the flow of events shapes, and is shaped by, decisions made by a human player or players during the course of those events." ${ }^{209}$ Wargames come in many types, from board games ${ }^{210}$ to full-fledged field exercises. ${ }^{211}$ The

${ }^{208}$ See id.

209 Peter Perla, So a Wargamer and a Black Swan Walk Into a Bar . . ., PhALANX, Dec. 2008, at 1, 2.

${ }^{210}$ The modem tradition of wargaming is usually traced to a complicated board game called "Kriegsspiel" popular in the Prussian Army in the early 19th century. See CHRISTOPHER GEORGE LEWIN, WAR GAMES AND THEIR History 40-44 (2012). When the game was demonstrated to the chief of the Prussian General Staff, Friedrich von Müffling, he is reputed to have said, "This is not a game! This is training for war! I must recommend it to the whole army." $I d$. at 43 .

211 See Brendan Koerner, How Do the Pentagon's "War Games" Work?, Slate (Sept. 17, 2002, 5:09 PM), http://www.slate.com/articles/ 
term also applies, and is used here to refer, to "conference room" roleplaying simulations. ${ }^{212}$

Philip Sabin, professor of strategic studies at King's College London, identifies two fundamental components of wargames, the first being, "an underlying ... . model of reality ... [intended to] provid[e] a synthetic experimental environment that mirrors in certain key respects the real range of potential courses and outcomes associated with the [crisis] concerned."213 The second, "equally fundamental" element of wargames is

an iterative set of active decision inputs by one or more players ... [who must] respond to the changing course of the simulated conflict, in order to maximize their relative or absolute performance in terms of artificial victory criteria established to reflect the real measures of success and failure associated with the actual [event]. ${ }^{214}$

The way this typically plays out is that the wargame "designers" create a scenario based on a particular model of reality, as well as on months of exhaustive research, and present it to different "teams" that need to react to the situation in some way. A financial crisis simulation designer for the World Bank describes it as follows:

news_and_politics/explainer/2002/09/how_do_the_pentagons_war_games_wo rk.html, archived at http://perma.cc/ZQD5-ZJẌH.

212 It is worth distinguishing between this type of simulation and other counterfactual tools regulators use, particularly the Dodd-Frank-prescribed "stress tests" and "living wills." See generally Baradaran, supra note 24. Stress tests try to model what would happen to bank capital levels under various adverse economic conditions. Id. at 159. They do not model contagion effects or liquidity squeezes, nor do they involve regulators assuming simulated roles or trying to respond to crises under conditions of uncertainty. Id. at 1299 . Living wills try to provide a blueprint for regulators to follow to wind down an institution in the event of failure. Id. at 1300-01. They are institution-specific and do not model systemic effects, nor (again) do they involve anything like role-playing simulations. $I d$. at 1307 . Despite the different (if overlapping) functions these regulatory tools serve, it is certainly possible that the lessons from, e.g., stress tests could inform the design of wargames, and that wargaming could, in turn, inform stress test design modifications.

213 PhiliP Sabin, Simulating War: Studying Conflict Through SimULATION GAMES 4 (2012).

${ }^{214} I d$. 
Participants (frequently the Minister of Finance, the Central Bank Governor, the Head of Bank Supervision, and other top national decision makers) receive a stream of (generally bad) news throughout the duration of the exercise, which describes the "scenario" (sequence of challenges) they must [manage] with the instruments provided by the (real or assumed) legal, regulatory, and operational
frameworks.

An event that fell short of a fully formed wargame, but which gives a good sense of the flavor of activity contemplated here, is a banking crisis simulation sponsored by The Economist at its "Buttonwood Gathering" in New York City in 2011. ${ }^{216}$ The simulation assigned key roles to prominent current and former regulators (most of whom had either actually served in the role they were playing, or had served in a position just below it). ${ }^{217}$ The regulators were presented with a scenario of a Lehman-like bank failure, and had to hash out a plan of action for dealing with it under the new Orderly Liquidation Authority created by Dodd Frank. ${ }^{218}$ As the players talked in front of a live audience over the course of an hour, they were able to work through many of the

\footnotetext{
${ }^{215}$ Aquiles Almansi, When Financial Crises Attacks, World BanK PRIVATE SECTOR DEV. (Aug. 1, 2013), http://blogs.worldbank.org/psd/when-financialcrises-attacks, archived at http://perma.cc/DCS4-NAK3.

${ }^{216}$ R.A., The Economist Stress Tests Dodd-Frank, ECONOMIST FREE EXCH. (Nov. 2, 2011, 1:03 PM) , http://www.economist.com/blogs/freeexchange/ 2011/11/banking-regulation, archived at http://perma.cc/TKV5-KS32.

${ }^{217}$ Larry Summers assumed his old role as Treasury Secretary; Donald Kohn, former vice chairman of the Board of Governors of the Federal Reserve, played the role of Fed chairman; Peter Fisher, former executive vice president of the New York Federal Reserve Bank, assumed the role of its president; Jerome (Jay) Powell, a former assistant secretary and undersecretary of the Treasury, played the role of Treasury Undersecretary for Domestic Finance; John Dugan, the former Comptroller of the Currency, played the chairman of the FDIC; Diana Farrell, former Deputy Director of the White House National Economic Council, played the role of its Director, and H. Rodgin ("Rodge") Cohen, former chairman of the law firm Sullivan \& Cromwell and the leading banking lawyer in the United States, played the role of Treasury General Counsel. Id. (laying out the roles beginning at about the 5:00 minute mark in the first video on the site).

${ }^{218} \mathrm{Id}$.
} 
intricacies of the new law and ponder the potentially dangerous consequences of each possible course of action they might choose. ${ }^{219}$ One of the advantages of the simulation (as I will highlight again below) was that it forced its participants and designers to come to terms with the constraints imposed by the law. During the question and answer session following the exercise, Jay Powell, who since the simulation has joined the Federal Reserve's Board of Governors, noted that he was surprised at "how poorly understood [Dodd Frank] is, even among people who you would think would know it cold."220

The Buttonwood Gathering simulation roughly corresponded to what wargame designers would term the "first move," comprising the teams' initial decisions or reactions to the game's opening scenario. ${ }^{221}$ A key question for wargame designers is what happens after the first move. Players' decisions or actions must be processed in some way (and new information may be added) to inform decisionmaking for a second, and then, possibly, a third and a fourth, move. ${ }^{222}$ Here the key question is "whether it [is] better to codify the game system within comprehensive rules . . or to base the modelling of" the impact of the team's decisions "on the wisdom and experience of an umpire." 223 Typically, there is a hybrid approach, ${ }^{224}$ with a "mission control" team to gather feedback, process moves, and keep the game running smoothly. ${ }^{25}$

It is worth highlighting three different (non-exhaustive and non-mutually exclusive) ways of generating consequences or outcomes

\footnotetext{
${ }^{219} I d$.

${ }^{220} I d$.

221 See Mark Herman et al., Wargaming for Leaders: STRATEgiC DECISION MAKING FROM THE BATTLEFIELD TO THE BOARDROOM 17 (2009).

${ }^{222}$ Wargames may last for less than a day or may extend to more than a week. Professional wargamers at the consulting firm Booz Allen Hamilton, Inc. say most games they design last for two days and comprise three moves:

Through trial and error, we have learned that a three-move exercise provides the flexibility to develop and complete the game without placing an unreasonable burden on the players' time. Three moves, furthermore, give the players enough experience with the possible Id. scenarios to get to the endgame and envision a resolution.

${ }^{223}$ SABIN, supra note 213 , at 31 .

${ }^{224} \mathrm{Id}$. at $31-32$.

${ }^{225}$ Paul Wright, Domestic Crisis Simulation Exercises: The UK, EUR. CENT. BANK (July 12, 2007), http://www.ecb.europa.eu/events/pdf/ conferences/sfi/Wright.pdf, archived at http://perma.cc/6TAW-7WYD.
} 
from players' or teams' key decisions during the first move. First, mission control could simply posit consequences of team actions. ${ }^{226}$ Ideally, this would be based on a combination of historical research on previous crises and a thorough understanding of current institutional frameworks. This approach is consistent with the view that wargames are not meant to be strictly predictive, but rather to present decision makers with plausible scenarios to help them practice working through the types of decisions they will have to make under extremely tight time constraints, and anticipate types of potential unintended consequences that may follow from a given decision or action. ${ }^{227}$

A second approach would be to assign players to serve as representatives of different institutions or even of categories of market participant, such as repo lenders. While financial crisis simulations typically do not involve the same degree of competition that military wargames do, one could try to inject competition into one by, for example, creating "bank accounts" for players representing short-term creditors of financial institutions and (a) imposing a cost for withdrawal while also (b) penalizing them for failing to withdraw prior to borrower failure. The goal-difficult but attainable, I believe-would be to simulate real run-like dynamics.

Third, one might employ agent-based models ("ABMs") as a way to try to map the chaotic, nonlinear dynamics that one sees in markets in a real crisis. ${ }^{228} \mathrm{An} \mathrm{ABM}$ is a computerized model that

specif[ies] rules that dictate how agents will act based on various inputs. Each agent individually assesses its situation and makes decisions on the basis of the rules. Once the model has specified the initial conditions and the agents' rules, the "world" is let loose and all subsequent events are driven by agent interactions. ${ }^{229}$

\footnotetext{
${ }^{226}$ See id.

${ }^{227}$ See supra Part III.C.

228 For an excellent account of ABMs, see generally Richard Bookstaber, Using Agent-Based Models for Analyzing Threats to Financial Stability (Office of Fin. Research, Working Paper No. 0003, 2012), available at http:/www.treasury.gov/initiatives/ofr/research/Documents/OFR_Working_Pa per_No3_ABM_Bookstaber_Final.pdf, archived at http://perma.cc/M59 $\mathrm{H}-$ LBAD.

${ }^{229}$ Id. at 4. Bookstaber explains that agents in such models "might represent biological organisms, social groupings, institutions, or physical entities." Id. In the context of financial crises, "the key agents for analyzing systemic risk are those that provide funding, those on the other side who are leverage, and those
} 
ABMs depend on model assumptions about (often heterogeneous) individual behavior, but these assumptions tend to be relatively straightforward and uncontroversial; as with the butterfly effect, ${ }^{230}$ the complexity arises from the interaction of agents, not from the structure of the agents' individual decision-making rules. The ABM allows us to see-given baseline assumptions about individual behavior and rules for interactions - what happens or might happen as the interactions play out. $^{231}$

A further central element in the design and implementation of wargames is, of course, the scope of participation. ${ }^{232}$ The focus of this Article is on decision-making personnel at key financial regulatory agencies. ${ }^{233}$ This would include, for example, not just the Treasury Secretary or the chairperson of the Federal Reserve, but the personnel one and two levels down who would participate in brainstorming and designing policy interventions in an actual crisis. It may also be worth considering involving industry participants, either during the design stage or in the game itself, or both. The upside to this would be adding potentially greater verisimilitude in terms of current market practices and institutions, as well as plausible market reactions to various policy moves. The downside would be that industry participants may be more likely to try to manipulate the wargaming process to influence regulation or supervision in their favor. ${ }^{234}$

who are liquidity providers." Id. at 16 . The sorts of rules that could be prescribed include

how leverage is to be reduced as a hedge fund approaches its margin limit or risk limit; how a bank plans to react in terms of increasing its haircuts to its clients, reducing its inventory and thus market-making posture, and liquidating assets; or how the participants in a short-term funding market are expected to react to an increase in counterparty or collateral risk.

Id. at 17 .

${ }^{230}$ See Ruhl, supra note 34 , at 887.

${ }^{231}$ See Bookstaber, supra note 228, at 2.

${ }^{232}$ See Herman ET AL., supra note 221, at 4.

233 The key institutions would be the Treasury Department, the Federal Reserve, and the FDIC. Other important agencies include the Securities and Exchange Commission, the Commodity Futures Trading Commission, and the Office of the Comptroller of the Currency.

${ }^{234}$ See, e.g., infra notes 290-96 and accompanying text. 


\section{B. Current Uses and Purposes}

Crisis simulations are not new to financial regulators and market participants. In the half-decade leading up to the financial crisis, the FDIC ran a series of increasingly complex bank resolution simulations. ${ }^{235}$ Since the passage of Dodd-Frank, the FDIC has run simulations to test its new Orderly Liquidation Authority to wind down non-bank financial institutions. ${ }^{236}$ Federal Reserve officials have participated in these FDIC-sponsored simulations, and Treasury officials have observed them. ${ }^{237}$ Financial industry trade associations have run large-scale simulations of financial firm resolution under the $\mathrm{OLA}^{238}$ and of a cyber-attack on the financial system. ${ }^{239}$ The World Bank has run at least twenty crisis simulations for different countries around the world since 2009..$^{240}$ Additionally, the European Central Bank actually ran a conference on modeling and simulating financial crises in 2007 , just before the actual crisis fully descended upon its participants. $^{241}$

${ }^{235}$ See Michael Krimminger, Contingency Planning \& Simulation Exercises: Practical Applications, EUR. CENT. BANK 7 (July 12, 2007), http://www.ecb.europa.eu/events/pdf/conferences/sfi/Krimminger.pdf,

archived at http://perma.cc/EN69-GJ9D. It is perhaps worth noting that of all the things that went wrong in the crisis, commercial bank resolutions were carried out smoothly and efficiently.

${ }^{236}$ Telephone Interview with Michael Krimminger, Partner, Cleary Gottlieb Steen \& Hamilton LLP (June 3, 2013).

${ }^{237} I d$.

238 See The Clearing House, Report on the Orderly LiQuidation AUthORITY RESOlUtion SyMPOSIUM AND SimUlATION (2013), available at https://www.theclearinghouse.org/ /media/Files/Association\%20Documents/2 0130117\%20TCH\%20Resolution\%20Simulation\%20Symposium\%20Report. pdf, archived at http://perma.cc/3FN9-TRHR.

${ }^{239}$ Press release, Sec. Indus. \& Fin. Mkts. Ass'n, SIFMA Announces Key Findings of Quantum Dawn 2 (Oct. 21, 2013), available at http://www.sifma.org/newsroom/2013/sifma-announces-key-findings-ofquantum-dawn-2/, archived at http://perma.cc/3ZNL-ABVT. The UK government (as opposed to a private trade group) has also run a crisis simulation of a cyberattack. Matt Scuffham \& Steve Slater, Cyber Attack 'War Game' to Test London Banks, ReUTERS (Nov. 11, 2013), http://www.reuters.com/article/2013/11/12/us-banks-wargameidUSBRE9AB00620131112, archived at http://perma.cc/NJ6R-J3E6.

${ }^{240}$ Almansi, supra note 215.

241 See generally European Cent. Bank, Simulating FinanCial 
These simulations have a number of non-controversial benefits. They can be an extremely efficient and effective way to familiarize players with constraints - legal, political, and policy - and to give regulators a better understanding of the constraints other regulators face. ${ }^{242}$ They can promote cooperation across agencies, and socialize key actors to new laws, regulations, or institutional arrangements. ${ }^{243}$ They can test institutional coordination, lines of communication, and decision-making processes in a way that goes beyond mere simulation to actual real-world stress-testing. ${ }^{244}$ These benefits alone may justify periodic crisis simulations. In the next section, however, I consider whether they can serve a further purpose - to help inform and improve the substance of possible responses. ${ }^{245}$

\section{The Power of Wargames}

There are two chief functions of wargames: training and research. ${ }^{246}$ While my focus is primarily on training - that is, preparing regulators to anticipate and respond to crisis-like dynamics-research is germane to the extent it may serve to improve the models used by regulators.

Wargames serve both purposes by providing participants with a sort of ersatz experience. First, the game may make new, or newly salient, facts available to its participants, which might help them hone,

\footnotetext{
INSTABILITY (2008), available at http://www.ecb.europa.eu/

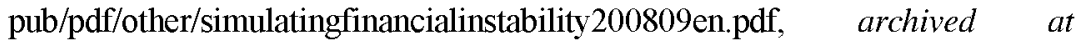
http://perma.cc/5243-CFY6.

${ }^{242}$ This can be a particularly important function of wargames given the degree to which the crisis response in 2008 and 2009 depended largely on creative use of the authorities that existed. Perhaps the most notable example of this was the use of the Exchange Stabilization Fund to guarantee money market funds. See PAUlsON, supra note 69, at 252. Since Dodd-Frank involved abolishing old authorities (such as the FDIC's broad guarantee powers) just as it created new ones (such as the Orderly Liquidation Authority), this type of creative lawyering will likely play an important role in the next crisis.

${ }^{243}$ See HERMAN ET AL., supra note 221, at 94.

${ }^{244}$ See id.

${ }^{245}$ As those familiar with our litigation system might observe, substantive outcomes are often driven by process and procedural rules, but these are just one among many factors that might determine the substance of a particular system.

${ }^{246}$ See Herman ET AL., supra note 221, at 7.
} 
amend, or replace their mental models. ${ }^{247}$ Gary Gorton, in his book Misunderstanding Financial Crises, contrasts social science on this front to the physical sciences, in which experimental evidence can decisively (if not instantaneously) shift the theoretical paradigm. ${ }^{248} \mathrm{He}$ cites as an example the famous 1887 experiment by Albert Michelson and Edward Morley that proved the death knell of the ether theory, ${ }^{249}$ as well as Galileo's use of the telescope to corroborate Copernicus's theories. ${ }^{250} \mathrm{He}$ tells us,

Seeing in the social sciences is complicated - there are no Michelson-Morley experiments. That is, there is never a single experimental result that once and for all demonstrates that a theory is dead, or alters how the world is seen. There is no telescope of Galileo to confirm the ideas of Copernicus. In the social sciences there is never an empirical result that causes the world suddenly to be seen differently. That only happens over a long period of time. But there are events that may sometimes serve the same purpose. The financial crisis is such an event. ${ }^{251}$

Revising our models for the better depends on our being disabused of mistaken notions; as experiments serve this purpose in the natural sciences, so may experience do so in the social sciences.

Wargames may approximate the effect of experience in disproving incorrect notions and helping us redraw our mental maps. ${ }^{252}$ While a wargame must be driven by model assumptions, the iterative feedback provided by human participants can conceivably generate outcomes that regulators and game designers had not fully considered before. $^{253}$ This can suggest new variations on, amendments to, or enrichments of the model or models regulators use in a crisis. It is also probably the best (and possibly the only) way to try to address a dilemma captured by Thomas Schelling, the Nobel Prize-winning game theorist: "One thing a person cannot do, no matter how rigorous his

${ }^{247}$ See id.

${ }^{248}$ Gorton, supra note 38 , at 201.

${ }^{249} \mathrm{Id}$. at $201 \& 246 \mathrm{n} .1$.

${ }^{250} I d$. at 201.

${ }^{251} I d$. (emphasis added) (citation omitted).

${ }^{252}$ See HeRMAN ET AL., supra note 221, at 7.

${ }^{253}$ See id. at 3-4. 
analysis or heroic his imagination, is to draw up a list of things that would never occur to him.

Changing regulators' mental maps - to build on the "connect the dots" metaphor described above-affects which dots they "recognize [as] worth connecting," and "remind[s them] which dots [they] need to complete the picture." ${ }^{, 255}$ In doing so, it also (for better or worse) can change their priorities. ${ }^{256}$

One example of the impact of actual experience on the formulation of policy arose from the Obama administration's reaction to the near success of the "underwear bomber" in his attempt to detonate a bomb on an airplane from Amsterdam to Detroit on Christmas Day, 2009. ${ }^{257}$ According to Ryan Lizza, writing in The New Yorker, this event had a big impact on Obama's team, and on their attitudes regarding the appropriate balance between security and privacy:

"The White House people felt it in their gut with a visceralness that they did not before," Michael Leiter, who was then the director of the National Counterterrorism Center, said. . . . "It's not that they thought terrorism was over and it was done with," Leiter said, "but until you experience your first concrete attack on the homeland, not to mention one that becomes a huge political firestorm - that changes your outlook really quickly." $\mathrm{He}$ added, "It encouraged them to be more aggressive with strikes"-drone attacks in Yemen and Pakistan - "and even stronger supporters of maintaining things like the Patriot Act. ${ }^{, 258}$

In a similar vein but in the context of financial crises, Gorton has claimed that "[t]o really understand a financial crisis one needs to be an eyewitness, to see it."259

The key question, however, is whether anything like the impact of a financial crisis can be achieved outside of actual real-world

${ }^{254} I d$. at 3. This dilemma is know as Schelling's "impossibility theorem." Id.

${ }^{255}$ KLEIN, supra note 52, at 185.

${ }^{256}$ See id.

${ }^{257}$ Ryan Lizza, State of Deception, NEW YORKER, Dec. 16, 2003, at 58.

${ }^{258} I d$.

${ }^{259}$ GORTON, supra note 38 , at 200. 
experience. Peter Perla and E.D. McGrady argue that it can; that, for example, well-told narratives or stories can create salience far beyond what data and analysis or academic writing can achieve. ${ }^{260}$ To illustrate, they recount the profound effect the novel The Cobra Event ${ }^{261}$ had on then-President Bill Clinton's thinking about biological terrorism. ${ }^{262}$ All the (copious) official analyses and assessments of the threat of biological terrorism did not affect Clinton as much as The Cobra Event: "The book found a curious resonance within Clinton, which led to a profound interest and concern about the threat. ${ }^{263}$ Clinton asked for an intelligence assessment of the book's plausibility, and this, combined with a White House wargame on biological terrorism carried out around the same time, led Clinton to push for a $\$ 294$ million increase to the counterterrorism budget. ${ }^{264}$ Perla and McGrady conclude that " $[\mathrm{t}] \mathrm{he}$ dramatization of the narrative in The Cobra Event (and the reinforcement of that experience in the game) seemed to access parts of President Clinton's imagination and attention that other sources of information could not." 65 They theorize that the "suspension of disbelief" that readers or viewers experience when drawn into a narrative on page or screen makes the narrative's message more "real" than a similar or substantively identical message conveyed by factual argument. ${ }^{266}$ Reading a great novel or seeing a great movie about an event is a far cry from experiencing it, but it does make the event's

${ }^{260}$ Peter P. Perla \& E.D. McGrady, Why Wargaming Works, NAVAL WAR C. REV., Summer 2011, at 111, 112 ("We propose the idea that gaming's transformative power grows out of its particular connections to storytelling; we find in a combination of elements from traditional narrative theory and contemporary neuroscience the germ of our thesis-that gaming, as a storyliving experience, engages the human brain, and hence the human being participating in a game, in ways more akin to real-life experience than to reading a novel or watching a video. By creating for its participants a synthetic experience, gaming gives them palpable and powerful insights that help them prepare better for dealing with complex and uncertain situations in the future.").

${ }^{261}$ See generally RichARd PRESTON, THE COBRA EVENT (1997).

${ }^{262}$ Perla \& McGrady, supra note 260, at 114.

263 Id. (citing TOM Mangold \& JEFF Goldberg, Plague Wars: The TERRIFYING REALITY OF BIOLOGICAL WARFARE 363 (1999)).

${ }^{264} \mathrm{Id}$.

${ }^{265} \mathrm{Id}$.

${ }^{266} \mathrm{Id}$. at 115 . 
lessons live in the mind in a way that a typical academic paper or journalistic report does not. ${ }^{267}$

Perla and McGrady argue that a "high-engagement" wargame can have an even more powerful effect on its participants than a welldone book or movie, because its participants are not mere passive recipients of the narrative, but help create it. ${ }^{268}$ They argue that "[t]he combination of venue, kinesthetic actions, social interactions, and dramaturgical effects-all moderated and responded to via active or passive control-allows the players to come closer to entering literally into the world of the game than they ever could in a watched or read narrative." 269

The salience of a "merged" narrative (one combining designers' and players' contributions) helps firmly place the various scenarios players encounter into the repertoire of patterns on which they can draw when problem-solving in a real crisis. ${ }^{270}$ What matters, to reiterate, is not that the particular scenarios are predictive of actual

${ }^{267}$ See id. It is, perhaps, instructive that in trying to convey not just the sequence of events during the crisis, but what it was like to try to respond to it, Geithner cites a movie, writing:

I didn't have a way to explain the terror of those days until later, when I saw The Hurt Locker, the Oscar-winning film about a bomb disposal unit in Iraq. What we went through on interminable conference calls in fancy office buildings obviously did not compare to the horrors of war, but ten minutes into the movie I knew I had finally found something that captured what the crisis felt like: the overwhelming burden of responsibility combined with the paralyzing risk of catastrophic failure; the frustration about the stuff out of your control; the uncertainty about what would help; the knowledge that even good decisions might turn out badly; the pain and guilt of neglecting your family; the loneliness and the numbness.

GEITHNER, supra note 70, at 200.

Later, Geithner draws parallels between financial crisis management and physicians' attempts to diagnose, treat, and triage, as represented in Atul Gawande's memoir Complications: Notes from the Life of a Young Surgeon and the TV series House M.D.: "That's financial crisis management more or less. It's diagnosis and treatment, prevention and cure, triage and surgery. The stakes are high and the outcomes are uncertain. Every case is different, but some protocols can be applied broadly." Id. at 509-10.

${ }^{268}$ Perla \& McGrady, supra note 260, at 218.

${ }^{269}$ Id. at 120-21. Perla and McGrady define dramaturgical effects as "signals that people send in social situations to establish both their identities and the overall social relationship." $I d$. at 120.

${ }^{270}$ See supra text accompanying notes $252-54$. 
crises, but that they are plausible, and provide a valid, if stylized, sense of the cause-and-effect dynamics in play during a crisis. ${ }^{271}$ Wargames, then, may help build a repertoire of experience that enriches regulators' mental models, increases their perceptual skills in reading jittery markets, and facilitates a greater degree of quick, efficient pattern matching and anomaly spotting. ${ }^{272}$

Because wargames make crisis dynamics more salient, they may also, in fact, help prevent crises, in addition to preparing regulators to respond to them. They may, that is, serve as an antidote to the complacency that inevitably settles in during long "quiet periods,",273 thereby increasing regulatory vigilance and encouraging proactive steps to address problems at a troubled institution or in a troubled market before they grow too large. ${ }^{274}$ In describing the early years of his tenure at the New York Fed, before the crisis hit, Geithner states,

I had vivid memories of the crises of the previous decade, [and] I wanted to examine the darkest plausible scenarios, the seemingly implausible "tail risks." In meeting after meeting, I argued that regulators and risk managers alike needed to set aside assumptions about the implausibility of a major shock and study the impact of that shock if it somehow happened. This provoked a fair amount of skepticism internally, and derision outside the Fed. ${ }^{275}$

The skepticism Geithner describes may ultimately be insurmountable, but well-designed wargames at least seem more likely than other methods to overcome it. Furthermore, a well-designed wargame may be the best way of accomplishing precisely what Geithner urgednamely, suppressing optimistic assumptions, even if players do not completely abandon such assumptions, in order to think seriously about how they should respond if a shock did have an unexpectedly large negative impact.

Robert Rubel, dean of the Center for Naval Warfare Studies, provides a good summation of the benefits of wargames, reaching

${ }^{271}$ See supra text accompanying note 227.

${ }^{272} C f$. KLEIN, supra note 52, at 35 (discussing how tacit knowledge is vital when coping with complex situations).

${ }^{273}$ See supra text accompanying notes $39-40$.

${ }^{274}$ See Perla \& McGrady, supra note 260, at 122.

${ }^{275}$ GeITHNER, supra note 70, at 93. 
conclusions in the military context that can apply in important ways to financial markets, as well: "Games allow players and observers to see relationships - geographic, temporal, functional, political, and otherthat would otherwise not be possible to discern. Seeing and understanding these relationships prepares the mind for decisions in a complex environment." 276 Of course, we cannot expect our understanding of these relationships, in either war or a financial crisis, to provide the sort of certainty that an engineer enjoys within the scope of her métier. Games can, however, produce "indicative" knowledge, or knowledge that "can indicate the possibilities of a projected warfare situation and certain cause-and-effect linkages," which can be very useful in evaluating complex problems. ${ }^{277}$

\section{Challenges and Obstacles}

While the potential benefits of wargames are impressive, a number of cautionary notes should be sounded. As Perla and McGrady state: "When it works, wargaming can appear almost magical in its power to inform and instruct; when it doesn't work, it can appear almost childish in its oversimplifications and abstractions. ${ }^{278}$

First and foremost, for a wargame to serve its purpose, the underlying model of reality on which the game is based must bear a sufficiently close relationship to the way things really are. ${ }^{279}$ This does not mean that the game must mimic reality in great detail - wargames useful for both research and training purposes can distill key elements of reality and focus on isolated cause-effect relationships. ${ }^{280}$ Nonetheless, in any such exercise, there is a risk that the model may simply fail to capture the relevant aspects of reality, in which case the wargame may be not just useless but counterproductive. ${ }^{281}$

\footnotetext{
${ }^{276}$ Rubel, supra note 191, at 112.

${ }^{277} \mathrm{Id}$.

${ }^{278}$ Perla \& McGrady, supra note 260 , at 111-12.

${ }^{279} I d$. at 123.

${ }^{280}$ Indeed, tractability demands such distillation—thus the insight famously captured by Jorge Luis Borges, that a map that corresponded point for point with what it represented would be useless. JORGE LUIS BORGES, On Exactitude in Science, in COLLECTED FICTIONS 325, 325 (Andrew Hurley trans., 1998).

${ }^{281}$ Perla \& McGrady, supra note 260 , at 123 . A variation on this objection is the concern that financial wargames may train regulators to "fight the last war." This objection has force if we expect wargames to help us prevent the shocks and vulnerabilities that may give rise to crisis dynamics. A central argument of this Article, however, is that once crisis dynamics kick in, they
} 
At first glance, this is no small quibble, given the variance in opinion on what led to the crisis in the first place. MIT economist Andrew Lo in his Twenty-One-Book Review of books on the crisis compares the various accounts to the movie Rashomon, in which a brutal crime is "described in contradictory ways by four individuals who participated in various aspects of the crime. ${ }^{, 282}$ Lo tells us that "[a]t the end of the film, we're left with several mutually inconsistent narratives, none of which completely satisfies our need for redemption and closure." 283 Drawing a parallel to the crisis, he argues that the movie's

message of multiple truths couldn't be more relevant as we sift through the wreckage of the worst financial crisis since the Great Depression. Even the Financial Crisis Inquiry Commission - a prestigious bipartisan committee of ten experts with subpoena power who deliberated for eighteen months, interviewed over 700 witnesses, and held nineteen days of public hearingspresented three different conclusions in its final report. Apparently, it's complicated. ${ }^{284}$

While opinions vary immensely, however, with respect to what caused the housing bubble in the first place, and with respect to how and why key financial institutions were so vulnerable to a shock, ${ }^{285}$ the gaps are significantly smaller with respect to how the crisis manifested itself and

display certain persistent structural similarities, even if the institutional manifestations of these dynamics differ greatly across crises. It is nonetheless essential for an effective crisis response that regulators stay up to date on the financial system's architecture and new market products, practices, and trends. Well-designed wargames could actually support this objective.

${ }^{282}$ Andrew W. Lo, Reading About the Financial Crisis: A Twenty-One-Book Review, 50 J. ECON. LITERATURE 151, 151 (2012) (book review).

${ }^{283} \mathrm{Id}$.

${ }^{284}$ Id. at $151-52$.

285 Candidates include, inter alia, lax regulation, an international "savings glut," securitization, government housing policy, skewed incentives at Fannie Mae and Freddie Mac, skewed incentives on Wall Street, derivatives, and the Gramm-Leach-Bliley Act (which removed the restriction on affiliations between broker-dealers and commercial banks). See generally FIN. CRISIS INQUIRY COMM'N, THE FINANCIAL CRISIS INQUIRY REPORT (2011), available at http://www.gpo.gov/fdsys/pkg/GPO-FCIC/pdf/GPO-FCIC.pdf, archived at http://perma.cc/UCD9-LQP6. 
what the appropriate steps to take were once the crisis was underway. ${ }^{286}$ Yet again, the distinction between predicting specific shocks, on the one hand, and predicting how initial losses can work their way through the financial system and affect the real economy, on the other, proves crucial. ${ }^{287}$ Indeed, Justin Fox recounts how, despite the deep fissures in opinions among economists with respect to monetary and macroeconomic policy choices since 2009, "[i]t's remarkable how widespread among academic economists ... was the view that on the whole" the crisis-fighting measures taken in the final months of 2008 were "the right thing to do."

In any event, regulators must operate based on some underlying models and theoretical assumptions, even if these models and assumptions are entirely tacit. The important thing, even as one operates within the constraints of a given model, is to be alive to new evidence that might undermine that model. Properly designed wargames might even help develop this flexible sort of attitude.

A second note of caution about wargames is that their effectiveness might be stymied by bureaucratic imperatives. This might, for example, be evidenced in the degree to which bad actions and events are underplayed in a scenario - what Perla and McGrady call "the sanitary fantasy." ${ }^{289}$ It may also manifest itself in the reaction of the bureaucracy to the lessons of the simulations.

One example involves a story recounted in Malcolm Gladwell's book Blink of the Millennium Challenge 2002 wargame"the largest and most expensive war game thus far in history." ${ }^{290}$ The "Blue Team" (representing the United States) had technological capabilities orders of magnitude greater than those of the "Red Team" (representing "a rogue military commander" and his army "somewhere in the Persian Gulf"). ${ }^{291}$ A retired Marine Corps general named Paul

\footnotetext{
${ }^{286}$ See infra note 288 and accompanying text.

${ }^{287}$ See supra text accompanying notes $31-34$.

288 Justin Fox, What We've Learned from the Financial Crisis, HARV. Bus. REV., Nov. 2013, at 94, 97. The consensus that the guarantees, capital injections, and other steps taken by regulators in late 2008 and early 2009 were appropriate and likely saved us from much worse economic damage is overwhelming but not unanimous. Contra Kenneth Ayotte \& David A. Skeel, Jr., Bankruptcy or Bailouts, 35 J. CORP. L. 469, 471 (2010) ("[W]e believe that allowing the bankruptcy process to work is preferable to an ad-hoc approach of preventing bankruptcy with last-minute rescue efforts.").

${ }^{289}$ Perla \& McGrady, supra note 260 , at 123.

${ }^{290}$ MALCOLM GLADWELL, BLINK 102 (2005).

${ }^{291} \mathrm{Id}$. at $102-05$.
} 
Van Riper was assigned the role of the Red Team rogue commander, and flummoxed both the Blue Team and the game designers by adopting a number of low-tech tactics to operate below Blue Team's radar. ${ }^{292} \mathrm{He}$ launched a surprise attack that (in the game) sank sixteen American war ships: "Had Millennium Challenge been a real war instead of just an exercise, twenty thousand American servicemen and women would have been killed before their own army had even fired a shot." $" 293$

Those running the wargame (which was to last two-and-a-half weeks) decided to refloat the sunken ships and to resurrect several of pro-U.S. leaders that Van Riper had (in the game) assassinated. ${ }^{294}$ More disturbingly, Van Riper reported:

"The day after the attack, I walked into the command room and saw the gentleman who was my number two giving my team a completely different set of instructions ... . It was things like-shut off the radar so Blue force are not interfered with. Move ground forces so marines can land without any interference. I asked, 'Can I shoot down one V-twenty-two?' and he said, 'No, you can't shoot down any V-twenty-two's.' I said, 'What the hell's going on in here?' He said, 'Sir, I've been given guidance by the program director to give completely different directions.' The second round was all scripted, and if they didn't get what they liked, they would just run it again." 295

When the wargame "was won by Blue Team in a rout," Gladwell reports, "the analysts at JFCOM and the Pentagon were jubilant." 296

While the bureaucratic bias in this story-which should perhaps be taken with a grain of salt ${ }^{297}$-is quite blatant, there are subtler ways for bureaucratic players to distort games to serve personal or agency agendas. The most obvious, but by no means only, example

${ }^{292} I d$. at $106-11$.

${ }^{293} I d$. at 110.

${ }^{294} I d$. at 145.

${ }^{295} I d$.

${ }^{296} I d$. at 146.

${ }^{297}$ See, e.g., Julian Borger, Wake-up Call, GuARDIAN (Sept. 5, 2002, 8:56 PM), http://www.theguardian.com/world/2002/sep/06/usa.iraq, archived at http://perma.cc/JT32-N6BS. 
is to play up results that would lead to more resources and authority being devoted to a given agency, and to ignore or bury results that might lead to resources or authority being diverted away from an agency. ${ }^{298}$ For this reason, one might, for example, be skeptical of the FDIC's or industry groups' conclusions about the efficacy of the OLA based on a wargame. ${ }^{299}$

If the decision makers at the very top of an organizational hierarchy are committed to a particular bureaucratic agenda, there may be no effective response to the problem. ${ }^{300}$ If, however, the concern is with those trying to influence the top-level decision makers, a possible response to this problem is to ensure that the wargames are not designed and run by the affected bureaucrats. Who, then, should run the wargames? The military sometimes uses outside consultants, who by all accounts can do excellent work, but this does not solve the problem of bureaucratic independence to the degree that the consultants hope to win further business from key decision makers within the sponsoring agency. ${ }^{301}$ Another possibility is to create an independent and autonomous unit devoted to running wargames for financial regulatory agencies, with appropriate immunity from bureaucratic pressures related to funding and job security. The Office of Financial Research might be one possible home for such an agency. ${ }^{302}$ Finally, academic institutions might also provide effective forums for wargames. ${ }^{303}$ One recent candidate is the recently established "Systemic Risk Institute" at

${ }^{298}$ Robert Rubel calls the uncomfortable messages of wargames "whispers," and warns against the temptation to ignore them. See Rubel, supra note 191, at 124.

299 See id. at 125 ("A sponsoring organization . . . cannot realistically be relied upon" to incorporate uncomfortable messages from the war games into its lessons learned, "especially if constrained by time, political imperatives, or the dictates of theory and doctrine ....").

${ }^{300}$ See id.

${ }^{301}$ See id. at 125 .

302 The Office of Financial Research was established by the Dodd-Frank Act. See About the OFR, U.S. DEP'T OF THE TREASURY, http://www. treasury.gov/initiatives/ofr/about/Pages/defaultaspx (last visited Dec. 30, 2014), archived at http://perma.cc/BZ3J-G6N6 (reporting that the Office of Financial Research is intended "to improve the quality of financial data available to policymakers and to facilitate more robust and sophisticated analysis of the financial system").

${ }^{303}$ See Rubel, supra note 191, at 125. 
Yale University. ${ }^{304}$ Over two weeks during the summer of 2014, top personnel "from U.S. and international regulatory agencies . . spent six hours each day in a classroom analyzing the government's response to various crises." ${ }^{305}$ The Institute organizers hope "[f]uture sessions could ... creat[e] a 'war room' scenario where regulators can discuss and learn how to respond to crises. ${ }^{9306}$

A further significant qualification is that wargames are costly - in the labor taken to design them and, above all, in making demands on the time of key decision makers. ${ }^{307}$ Malcolm Knight, former General Manager and Chief Executive Officer of the Bank of International Settlements, stated at a European Central Bank conference on crisis simulation in 2007 ,

"War games" that are played in crisis simulation exercises are at a preliminary stage. I have been particularly impressed by the high resource costs of these exercises, in terms of the amount of work that goes into designing the scenarios that trigger the crises and the key problems to be solved; the amount of time and effort of senior policymakers required to play the game; and the difficulties of taking account of the strategic reactions of the various players, particularly in the private sector, after the initial shock. Because these costs are high, such crisis simulation exercises are likely to be undertaken only infrequently. ${ }^{308}$

But Knight goes on to state that "[g]iven the rate of innovation in the financial system, this raises the concern that policymakers may be out of date when a crisis actually occurs"-and his proposed solution to this is ensuring that regulators are up to date "on the structure and key business activities of the major financial institutions in their

${ }^{304}$ Ryan Tracy, No S'More Crises: Global Financial Regulators Gather for Summer Camp, WALL ST. J. (Aug. 1, 2014, 11:20 AM), http://online.wsj.com/ articles/no-smore-crises-global-financial-regulators-gather-for-summer-camp1406906444.

${ }^{305} \mathrm{Id}$.

${ }^{306} I d$.

${ }^{307}$ See Malcolm Knight, Interventions at the Policy Panel, in SIMULATiNG FINANCIAL INSTABILITY, supra note 241, at 35, 36.

${ }^{308} I d$. 
jurisdictions" (something one would hope regulators have a handle on in any event). ${ }^{309}$

The cost concern is significant, but if wargames were to become routinized, it is possible that the design costs would fall as a cadre of wargame "architects" developed expertise. ${ }^{310}$ A marginal costbenefit calculation for top regulators' time (even if it were possible) is beyond the scope of this Article, but even Knight - speaking, it should be noted, prior to the unfolding of the global financial crisis-seems to admit some time commitment from top officials is worthwhile. ${ }^{311}$

Another potential drawback is that wargaming financial catastrophes could have an adverse impact on market confidence in stressful times. Paulson reports that his Treasury staff had, at one point, considered running "tabletop exercises on the failure of a governmentsponsored enterprise like Fannie Mae and the collapse of the dollar, but decided against doing so for fear that word might leak to the press, leading the public to believe we thought these scenarios imminent." 312 This concern, again, is serious, but transparency and routinization could likely dissipate much of its force. The particular fear is that the market will view the subject of the exercise as a signal of what regulators (with a more comprehensive and complete view than market participants) fear might actually happen. ${ }^{313}$ If regulators look panicked, it could precipitate the very run everyone had hoped to avoid. But if the market comes to understand that the exercises are done on a routine basis with scenarios picked far in advance, it seems less likely they will see wargames as an indication of current heightened regulatory fears about a particular scenario or institution.

Finally, player buy-in is important, but might be difficult to attain if scenarios are too negative during a period of stability. ${ }^{314}$ This is the flipside of the potential advantage wargames have in getting people to think about dark scenarios that they do not expect to occur. Former Federal Reserve governor Elizabeth Duke observed in a speech in 2010 that:

${ }^{309} \mathrm{Id}$.

${ }^{310}$ See Rubel, supra note 191, at 126-27.

${ }^{311}$ See Knight, supra note 307 , at 40.

${ }^{312}$ PAULSON, supra note 69, at 52.

${ }^{313}$ See id. at 52.

${ }^{314}$ See GEITHNER, supra note 70, at 93 ("A financial CEO who was unusually cautious about leverage during the boom probably would have been fired before the bust. Many bank executives didn't even want to think about truly extreme events."). 
[T] he credibility of a simulation exercise comes from its similarity to real world conditions that students have experienced. [Prior to the crisis], . . if I had tried to simulate an environment in which interest rates dropped from more than 5 percent to near zero in 16 months, unemployment went to 10 percent, housing prices dropped nearly 30 percent, mortgage delinquencies hovered around 10 percent, and credit card loss rates went over 10 percent, nobody would have believed it. $^{315}$

The inability to believe something is possible may be unsolvable with respect to individual decision makers, but if anything short of its actual occurrence can address this, it must be the sort of merged, lived narrative that a wargame entails. As noted above, wargames may be the best antidote to the complacency that inevitably arises from a long period without extreme turmoil. ${ }^{316}$

\section{Conclusion}

Rare catastrophic events that are malleable to human intervention pose a special challenge: we want to be sure that our interventions shape events to our advantage, but the infrequency of the event means that respondents are typically learning on the job with each new crisis. ${ }^{317}$ Preventing such catastrophes must be a priority, but exclusive reliance on ex ante measures would be misguided, leaving us worse off when the next crisis (inevitably) hits. ${ }^{318}$ The potentially stratospheric costs of a financial crisis demand that we devote some thought and energy to ensuring effective interventions when panic strikes again. Wargaming provides a unique way of preparing and training financial regulators to make effective loss-mitigating decisions in a crisis. ${ }^{319}$

${ }^{315}$ Elizabeth A. Duke, Member, Bd. of Governors of the Fed. Reserve Sys., Moving Beyond the Financial Crisis 1 (June 8, 2010), available at $\mathrm{http}: / / \mathrm{www}$.federalreserve.gov/newsevents/speech/duke20100608a.pdf, archived at http://perma.cc/ST8H-6SY6.

${ }^{316}$ See supra notes $274-75$ and accompanying text.

${ }^{317}$ See supra notes $205-07$ and accompanying text.

${ }^{318}$ See supra text accompanying notes $31-34$.

${ }^{319}$ See supra Part III.D. 
The policy proposal advanced here is not a silver bullet, and should be seen as a supplement to, rather than replacement for, other essential measures such as ensuring sufficiently high capital levels at key financial institutions. ${ }^{320}$ It nevertheless addresses an important hole in the regulatory scheme that has no other plausible plug. Crises will come, and when they do we must be ready. The relative scarcity of opportunities to build real-world experience in responding to crises creates a need for synthetic substitutes. ${ }^{321}$ Wargames can meet this need.

${ }^{320}$ See Perla \& McGrady supra note 260, at 125.

${ }^{321}$ See supra Part III.G. 